\title{
Recent advances and challenges on application of tissue engineering for treatment of congenital heart disease
}

\author{
Antonia Mantakaki ${ }^{1}$, Adegbenro Omotuyi John Fakoya ${ }^{\text {Corresp., }}{ }^{2}$, Fatemeh Sharifpanah ${ }^{3}$ \\ ${ }^{1}$ Surgical Division, Teleflex Incorporated, Bristol, United Kingdom \\ 2 Department of Anatomical Sciences, University of Medicine and Health Sciences, Basseterre, St. Kitts and Nevis \\ 3 Department of Physiology, Faculty of Medicine, Justus Liebig University, Giessen, Germany \\ Corresponding Author: Adegbenro Omotuyi John Fakoya \\ Email address: gbenrofakoya@gmail.com
}

Congenital heart disease (CHD) affects a considerable number of children and adults worldwide. This implicates not only developmental disorders, high mortality, and reduced quality of life but also, high costs for the healthcare systems. CHD refers to a variety of heart and vascular malformations which could be very challenging to reconstruct the malformed region surgically, especially when the patient is an infant or a child. Advanced technology and research have offered a better mechanistic insight on the impact of CHD in the heart and vascular system of infants, children, and adults and identified potential therapeutic solutions. Many artificial materials and devices have been used for cardiovascular surgery. Surgeons and the medical industry created and evolved the ball valves to the carbon-based leaflet valves and introduced bioprosthesis as an alternative. However, with research further progressing, contracting tissue have been developed in the lab and tissue engineering (TE) could represent a revolutionary answer for CHD surgery. Development of engineered tissue for cardiac and aortic reconstruction for developing bodies of infants and children can be very challenging. Nevertheless, the use of acellular scaffolds, allograft, xenografts, and autografts are already very common. Seeding of cells on surface and within scaffold is a key challenging factor for use of the above. The use of different types of stem cells has been investigated and proven to be suitable for tissue engineering. They are the most promising source of cells for heart reconstruction in a developing body, even for adults. Some stem cell types are more effective than others, with some disadvantages which may be eliminated in the future. 
2 Recent advances and challenges on application of tissue engineering

3 for treatment of congenital heart disease

4

5 Antonio Mantakaki', Adegbenro Omotuyi John Fakoya ${ }^{2 *}$, Fatemeh Sharifpanah ${ }^{3}$

6

7 1Surgical department, Teleflex, Bristol, United Kingdom.

8 2Department of Anatomical Sciences, University of Medicine and Health Sciences, 9 Basseterre, St. Kitts.

${ }^{3}$ Department of Physiology, Faculty of Medicine, Justus Liebig University, Giessen, Germany.

12

*Corresponding author: Dr. Adegenro Omotuyi John Fakoya

Email: gbenrofakoya@gmail.com

15 
25 ABSTRACT

26 Congenital heart disease (CHD) affects a considerable number of children and adults worldwide.

27 This implicates not only developmental disorders, high mortality, and reduced quality of life but 28 also, high costs for the healthcare systems. CHD refers to a variety of heart and vascular 29 malformations which could be very challenging to reconstruct the malformed region surgically, 30 especially when the patient is an infant or a child. Advanced technology and research have offered 31 a better mechanistic insight on the impact of CHD in the heart and vascular system of infants, 32 children, and adults and identified potential therapeutic solutions. Many artificial materials and devices have been used for cardiovascular surgery. Surgeons and the medical industry created and evolved the ball valves to the carbon-based leaflet valves and introduced bioprosthesis as an alternative. However, with research further progressing, contracting tissue have been developed in the lab and tissue engineering (TE) could represent a revolutionary answer for CHD surgery. Development of engineered tissue for cardiac and aortic reconstruction for developing bodies of infants and children can be very challenging. Nevertheless, the use of acellular scaffolds, allograft, xenografts, and autografts are already very common. Seeding of cells on the surface and within scaffold is a key challenging factor for use of the above.

The use of different types of stem cells has been investigated and proven to be suitable for tissue engineering. They are the most promising source of cells for heart reconstruction in a developing

43 body, even for adults. Some stem cell types are more effective than others, with some 44 disadvantages which may be eliminated in the future. 


\subsection{INTRODUCTION}

Congenital heart diseases (CHD) refer to the abnormal formation of the infant's heart, great thoracic vessels and heart valves during intra-uterine development [1]. CHD is different from the acquired heart diseases which occur because of lifestyle or aging [2]. The abnormalities are structural defects, such as valve defects, intravascular or intracardial stenosis, congenital arrhythmias or cardiomyopathies which greatly affect the early and future life of a CHD patient $[1,3]$. People born with CHD need immediate medical care after birth which further continues throughout their lives. In 2010, it was estimated that only in the USA approximately 2.4 million people suffered from CHD and more than half of them were adults [4]. In Europe, for instance, for the period of 2000 to 2005, about 36,000 live births per year were diagnosed with CHD [5]. The number grows bigger when including the unborn that were diagnosed with CHD and died either by the termination of pregnancy or by intrauterine death or even neonate death[5]. In the UK, about 8 in every 1,000 live babies born have a heart or circulatory condition [1]. Some estimate those numbers to be higher and, commonly, percentages of each type of CHD change depend on the geographical area of investigation [6,7], table 1 further mentions other CHD frequencies for other countries. CHDs not only have an effect on the individual's and their family's life but also, have a huge financial impact on healthcare system. According to NHS England for the financial year 2013/14 the total spent on CHD was $£ 175$ million [8] and in the US the total cost for CHD treatment in 2008 was approximately $\$ 298$ billion [9]. In general, the number of children and adults being diagnosed with CHD increases due to improved technology of diagnostic tools [6].

CHD can be diagnosed using transabdominal fetal Doppler echocardiography. Such prognostic protocols are performed in high-risk groups of pregnant women, like those with a family history of CHD [10]. In adults with CHD, the most effective diagnostic practice is transesophageal echocardiography, electrocardiogram, pulse oximetry, X-rays, cardiac catheterization and MRI [11]. The CHDs are managed by surgery, and the efficiency of this approach is largely dependent on the materials that are used during the surgery. These materials are expected to be close to the native cardiac tissue in both structure and function. In structure, CHD could present extremely complicated malformations which cannot be spontaneously or by singular surgical procedure reconstructed, hence the dire need for more research into biomaterials for Tissue Engineering (TE). 
76 The recent extensive research focuses on possible ways to fabricate a near ideal tissue. So far, TE 77 appears to be the way forward in creating ideal tissue that can probably mimic the native heart tissue both in structure and function. TE refers to creation of functional three-dimensional tissue using biomaterials and cells for replacement or restoration of damaged organs and/or parts of them. TE is the most promising approach at the present for CHD, as treatment can be "patient-specific" and the engineered tissue could adjust to the developing body of the recipient. Many would think that TE is an idea which conceived and developed in a very recent past. However, it has been proven that tissue regeneration and TE is a concept which was born thousands of years ago, and it has inspired Greek mythology, history, arts, and religion. In arts, religion inspired the well-known painting of "Healing of Justinian" based on the miracle of St. Cosmas and St. Damian, physicians and Christian martyrs who appear to have transplanted the leg of an Ethiopian to the body of a patient [12]. The closest to an artificial replacement of a body part was discovered in Egypt on a mummy which had a wooden replacement of the hallux [13]. However, today, TE involves a combination of creating scaffolds and cell seeding. With regards to the heart, the most commonly used and known artificial parts are the mechanical heart valves and conduits $[14,15]$. The first artificial heart valve was placed on live patients only in the last century $[14,16]$. In 2003 , some evidence was presented to support the regenerative ability of the adult heart [17].

This evidence shows the existence of cardiac stem/progenitor cells which can differentiate into new cardiomyocytes and participate in cardiac regeneration [17]. In contrast to the adult heart, infants' and children's hearts regenerate in a larger capacity because the regenerative ability is proportionally correlated to age [18]. Additionally, there is an insufficient number of heart donors which becomes more challenging because of the heterogeneous relation of recipient-donor and the diverse range of CHD. These points result in high mortality rates and further financial costs to the healthcare systems [19]. However, only a small number of preclinical studies have focused on CHD treatments $[20,21]$. Stem cells (SC) have been widely investigated mainly for myocardial infarction (MI), as it is currently the leading cause of morbidity and mortality worldwide [22]. Cell seeding is a fundamental component of TE. Several studies have examined the possibility of direct cell delivery in the damaged area, cardiac patch implantation and engineered heart tissue, with the former being the most popular [20, 22, 23]. All possible types of stem cells are under investigation to identify the most appropriate cell types for tissue engineering using in corrective surgery of 
106 CHD. This review looks into the congenital heart diseases, biomaterials and scaffolds, and, types

107 of stem cells used in TE.

108

109

\subsection{METHOD}

110

111

112

113

114

115

116

117

118

119

120

121

122

123

124

125

126

127

128

129

130

131

132

133

134

This paper was based on review articles and reports in reputable peer-reviewed journals and government websites. The research was conducted using Medline on OvidSP, PubMed, google scholar, website, books, e- books, and reports. The words "congenital heart disease", "tissue engineering", "surgical treatment", "stem cells", "scaffolds", "biomaterials" and a combination of those were used to retrieve literature from the databases.

\subsection{Congenital Heart Disease: Types, malformations, presentations and interventions}

CHD includes a diverse range of conditions which shows a variety of symptoms, indications, and malformations detected during pregnancy or after birth [11]. However, these malformations are much influenced by the age of diagnosis [6]. The etiology of CHD is unknown, but it is generally accepted that many factors or a combination of them could contribute to CHD and considered to be caused by multifactorial inheritance. These factors could be genetic, epigenetic or environmental factors such as alcohol and drugs consumption, as well as viral infections like Rubella [11]. The severity of the disease varies, and a number of malformations could be present in each case. Based on the severity of CHD, they are categorized to mild, moderate, and severe CHDs, which the latter is subcategorized to Cyanotic and Acyanotic lesions [19]. The most frequent type of severe CHD is Ventricular Septal Defect (VSD) [24]. VSD could cause myocardial defects which disappear in the first year of the infant's life [24]. Nevertheless, the VSD could also cause some malformations which can be managed only by surgical intervention, that is, infant pulmonary hypertension [6, 24]. The other CHD type is Atrial Septal Defect (ASD) which is usually asymptomatic and in most of the case will only be diagnosed in adulthood [6]. Atrioventricular septal defects (AVSD) is mainly observed in trisomy 21 [6]. AVSD is usually characterized by "complete AV-canals with one common AV valve for both ventricles and an interatrial and intraventricular communication" and requires surgical correction. The results of long-term patient follow up after operation have shown very satisfactory survival rate [25]. 
135 Another type of CHD, tetralogy of Fallot (ToF), is characterized by VSD, pulmonary stenosis, 136 right ventricular hypertrophy and over-riding of the aorta [26]. Infants who suffer from ToF will 137 require immediate surgical intervention for better survival rates and avoid cyanosis, a result of 138 inadequate pulmonary blood flow [26]. Calcific Aortic Valve (CAV), another type of CHD, is a 139 disease which progresses slowly and results to a mild valve thickening and obstructing blood flow, 140 aortic sclerosis or severe calcification with impaired leaflet motion [27]. CAV presents many 141 similarities with arteriosclerosis in adults which is caused by lifestyle or aging [27]. However, 142 CAV is a congenital, progressive disease which could be diagnosed in patients less than one year 143 of age, and those in childhood or even adulthood [28, 29]. Table 1 summarizes the frequencies of 144 congenital heart diseases, while Table 2 summarizes the types of CHDs, presentations and possible 145 management.

146

147 Table 1: Frequencies of CHD in some regions

Table 2: Types, presentations and management of CHDs 
154 Some types of the CHDs are misdiagnosed, undiagnosed, or diagnosed very late in life which could 155 make a successful treatment challenging [64].

156 In contrast to the adult heart, infants' and children's hearts regenerate in a larger capacity because 157 the regenerative ability is proportionally correlated to age [18]. Additionally, there is an 158 insufficient number of heart donors which becomes more challenging because of the 159 heterogeneous relation of recipient-donor and the diverse range of CHD. The mortality rate among 160 all patients who are waiting for any type of organ transplantation is highest in infants who wait for 161 heart transplant $[65,66]$. CHDs patients usually require medication, cardiac catheterization or a 162 series of surgical interventions throughout their life $[11,66]$. This among other risks increases the 163 chances of HLA-sensitization which eventually makes it more difficult to find a cross-match [66].

164 The main challenge with artificial materials is the alterations in the size and function of the heart 165 from the neonatal period, infanthood, and to adulthood, to which current artificial materials cannot 166 adjust to [11]. The need for early intervention is essential for normal physical and cognitive 167 development [64].

168

169

170

171

172

173

174

175

176

177

178

179

180

181

182

The use of bioprosthetics including allografts and xenografts is widely used for treatment of CHD as they present good survival rates in the patient and fewer interventions throughout their lifetime [65]. The observed symptoms, defects, and complications upon bioprosthetic treatment of CHD patient could differ from case to case [24, 64].

\subsection{Heart, a complex organ for tissue engineering}

Unlike other human tissue, cardiac tissue is a more complex tissue considering not only because of its mechanical and structural function but also due to its electrical properties as well. The human heart mainly consists of cardiomyocytes, functions as a blood pump which is regulated by the electrical signal generated by the pacemaker cells in the sinoatrial nodes. This signal is directed and spread through the atrioventricular node to Purkinje fibers, and this is highly important for the direction of blood flow [67]. The diastolic and systolic function of the heart is necessary to be synchronized and adjusted according to the body needs. The isolation of this signal from the rest of cardiac tissue is as important as this electrical signal by himself. This importance is achieved by the extracellular matrix (ECM) of heart which is also responsible for mechanical support and 
183 endurance [67]. Aside the functional aspects which briefly mentioned above, the structural aspects

184 (the cardiomyocyte and its ECM) are another factor for strong consideration in the success of TE.

185 To yield an engineered tissue with the best functionality, this engineered tissue must be similar in 186 every sense to the native tissue. The ECM of the heart is mainly a complex mesh of structural 187 elements such as cardio fibroblasts and collagen fibrils, and non-structural elements such as 188 proteoglycans, glycosaminoglycans, and glycoproteins [68, 69] among other components. 189 Repairing the heart using materials which do not have or do not comply with the above 190 characteristics and cannot work in harmony with the host-heart, will result in a non-efficient 191 functioning heart accompanied by a series of complications. The concept and act of repairing the 192 heart using various engineered techniques has evolved over the years from the use of artificial 193 heart valves and grafts to bioprosthesis, and currently forward to the use of biomaterials and 194 scaffolds cells.

\subsection{Artificial Heart Valve and Grafts}

197 Charles Hufnagel was the first to experiment on animals with an artificial valve which he designed 198 in the 1940's [15]. A few years later, the same type of valve was transplanted into humans [15]. Nonetheless, Hufnagel's valve required changes which were succeeded by Harken-Soroff and later by Starr-Edwards ball valve [15]. Following several improvements, the latest version is made of pure carbon as a lighter, smoother material for blood flow and more durable in comparison to other

202 materials [14]. Due to the position of the valve, there is a high transvascular pressure which leads to 'impact wear' and 'friction wear' [14]. Further complications with the use of valve replacements include inflammation around the prosthesis and calcification of the valve itself [70]. The main disadvantage of artificial valves is the thromboembolic risk which leads to lifetime treatment with anticoagulants. This type of treatment involves various complications and brings different risks to patient [14]. Similarly, to valves, artificial vascular grafts have been used for many years as a surgical treatment for CHD [71]. Nevertheless, they provoke an inflammatory response, and they are much less flexible than the body's natural tissue [64]. Originally porous fabric knitted of Dacron and polytetrafluoroethylene (PTFE) was used for stenosis treatment. Later alterations in the porosity of fabric were introduced to prevent the material's corruption [64]. The first attempt

212 to combine biomaterials with patient's cells was made by Wesolowki and colleagues by 
213 "preclotting the graft with the patient's blood" [64]. However, future attempts to produce 214 successful results created many doubts about the actual function of cells following citation on clot 215 [64]. Nonetheless, both artificial heart valves and conduits require continuous use of 216 anticoagulants. Remarkably, they do not grow with the patients' heart as patients with CHD are highly likely to require surgical intervention when they are an infant or a child $[64,72]$.

\subsection{Bioprosthetics: Allograft, Xenografts, and Autografts}

221

222

223

224

225

226

227

228

229

230

231

232

233

234

235

236

237

238

239

240

Allograft heart valves and arterial grafts are collected from deceased humans. In contrast, xenografts are harvested from porcine and bovine animals including heart valves and carotid arteries $[14,16,70]$. Allografts and xenografts came into the picture as an alternative to artificial valves and conduits. Their main advantage is that they do not require lifetime treatment with anticoagulants [14, 73, 74]. Animal tissue is treated with glutaraldehyde [73]. Glutaraldehyde is a five-carbon bifunctional aldehyde used to stabilize tissue to protect from chemical and enzymatic degradation and maintain "its mechanical integrity and natural compliance" [73]. Also, treatment is necessary to reduce immunogenicity of the xenograft by decellularization and sterilization of the tissue [73]. Like xenograft, allografts also need treatment before transplantation and can even be cryopreserved [65]. Despite the great advantage, a number of complications are related to bioprosthetic grafts related to their preparation [73].

The risk of cytotoxicity leading to inflammation, as well as the partial loss of mechanical properties of tissue, have been reported [73]. Moreover, calcification is often observed in infants and children with bioprosthetics. Many efforts are being made to find out an alternative treatment for heart bioprosthetics therapy. However, there is a controversy regarding their efficiency [73].

In a study carried out by Homann and colleagues, the outcomes of 25 years using allografts and xenografts for reconstruction of the right ventricular outflow tract showed $66 \%$ survival at 10 years' follow up. Furthermore, patients with allografts had a mean reoperation-free interval time of 16 years in contrast to the xenograft recipients which this interval time is 10.3 years [65]. Allografts may present better outcomes, but they are not in abundance like xenografts. Therefore, 
241 many studies are concentrating on the development of tissue valves and vascular grafts created by

242 stem cell-seeded on artificial or natural scaffold [16].

243 The relatively recent "CorMatrix" patch fabricated from the decellularized porcine small intestinal 244 submucosa extracellular matrix (SIS-ECM) mainly composed of collagen, elastin, glycan, and 245 glycoproteins have been introduced into cardiac surgery. SIS-ECM has not only been used in animal models for cardiac surgery [65-77], but also in humans studies, for cardiac and vascular reconstructions such as; augmentation of the tricuspid valve [78], vascular repair of ascending aorta, aortic arch, right ventricular outflow tract, pulmonary artery, valvular reconstruction [79], and closure of septal defects [80]. The study by Witt et al. reported a small risk of stenosis when SIS-ECM is used in the reconstruction of the outflow tracts and great vessels. Interestingly, the SIS-ECM has effectively proved the function in the high-pressure vessels [80]. The pitfall of this study, however, was the short follow up period.

253

254

255

256

257

258

259

260

261

262

263

264

265

266

267

268

269

A very common surgical practice for CHD is the use of pericardial patches for repairing the septal defect [64]. The autologous pericardium is the best choice for infants as it is free, it does not provoke any immune-response, and it is sterile. Even though it requires some preparation before application, autologous pericardium creates less fibrotic tissue in comparison to Dacron [64]. Allograft pericardium is available, but quite a few risk factors are associated with its use [64]

\subsection{Biomaterials and Scaffolds for tissue engineering}

Generally, scaffolds work as a primary base for cells to enhance and produce relevant tissue. The scaffolds should have specific morphological, functional, and mechanical properties to support cells survival and differentiation [23]. Biomaterials used to produce scaffolds should be made of components which will accommodate the above characteristics and create a friendly cell microenvironment [23]. The previously mentioned characteristics apply for all different types of engineered tissue, and the goal is to mimic host tissue in the best possible way. With regards to artificial and bioprosthetic cardiac correction choices, scaffolds and biomaterials should contain various properties such as being biodegradable, biocompatible, flexible and durable and absence of immunogenicity and calcification. Due to the variety of sizes of patients' heart and defects, designed scaffolds should have various size and ability to be able to grow and adapt to the heart 
270 [74]. The biomaterial should allow neo-vascularization for adequate oxygenation of the tissue,

271 create minimal scaring tissue and thrombotic risk, as the latter could lead to life treatment with

272 anticoagulants [81, 82]. Furthermore, these biomaterials scaffolds should be bioactive, meaning

273 they should enhance cellularization in vitro and in vivo, and optimize cell efficiency and degrade

274 at a desirable rate [82]. What is more, biomaterials and scaffolds should be in abundance and cost-

275 effective, as high cost could restrict development and use of it in TE as a routine therapeutic choice

276 [83]. The most common biomaterials for cardiac and vascular TE used today are synthetic, and

277 natural polymers [67], and the electrospinning technique has been proven to be the most efficient

278 way to produce scaffolds with these biomaterials [84].

\subsubsection{Synthetic polymers for cardiac scaffolds}

281 The easiest way to have materials in abundance is to manufacture them. The need for suitable

282

283

284

285

286

287

288

289

290

291

292

293

294

295

296

297

298

299

biomaterials for cardiac tissue repair has triggered development of synthetic polymers which are easy to fabricate and manipulate. These polymers can be manipulated with respect to their physical properties, molecular weight, heterogeneity index, and degradation speed [85]. Many synthetic polymers are biocompatible and have excellent mechanical properties which make them a popular choice for sutures and mesh production [67]. Frequently used polymers in cardiac surgery are polyglycolic acid (PGA) and polylactic acid (PLA). These two polymers have been used as a single biomaterial or as 50:50 composite to reconstruct tissue-engineered vascular grafts for treating children with congenital heart disease [86]. Carrier et al. Presented acceptable ultrastructural features and metabolic cell ability when cells were cultured on PGA scaffold in a rotating bioreactor $[87,88]$. The rotating bioreactor increases cell adherence and decreases cell damage [87]. The highest concern with synthetic polymers is their toxicity. Therefore, the use of poly-Llactic acid (PLLA) has increasingly become more of interest. PLLA has demonstrated very good results when combined with bone marrow mesenchymal SC (BM-MSC) for vascular tissue engineering [89]. In vivo studies by Hashi et al showed that nanofibrous scaffolds created with PLLA can remodel in both cellular and ECM content, similar to that of the native artery [89]. Both acellular and were implanted into the common carotid artery of live animal models (rats). The cellular scaffold was cited with MSC and "exhibited very little platelet aggregation on the luminal surfaces" compared to the acellular grafts. This is due to the antithrombogenic property of MSC 
300 [89]. PLLA, when degraded in the body, can "be excreted in carbon dioxide and water" [67]. 301 Polyurethane, unless copolymerized, is biocompatible but not biodegradable. Polyurethane has 302 been successfully experimented in combination with other materials for cardiac tissue repair, such 303 as siloxane films [90, 91], cellulose [92], urea [93], PLLA [94]. Poly ( $E$ - caprolactone) in 304 combination with other biomaterials have also been proven to be efficient composite for cardiac 305 tissue repair. They have been used in combination with PLLA alone [95,96] PLLA and collagen 306 [97], polypyrrole and gelatin [98], polyglycolic acid [99], poly (hydroxymethyl glycolide) 307 [100], chitosan and gelatin [101].

Based on our understanding of the heart as an electroactive tissue, Hitscherich and colleagues have created a piezoelectric scaffold fabricated by electrospinning Polyvinylidene FluorideTetrafluoroethylene (PVDF-TrFE) for cardiac tissue engineering [102]. The combination of synthetic with natural polymers has been suggested to increase cell adherence. However, pure natural polymers have also been examined as an option for polymers [67].

\subsubsection{Natural polymers for cardiac scaffolds}

316

317

318

319

320

321

322

323

324

325

326 327

Natural polymers are biodegradable, biocompatible and easily manipulated matrices composed of complex elements which make up the native tissue [103] The natural polymers used so far for cardiac repair include collagen, gelatin, alginate, silk, fibrin, chitosan and hyaluronic acid [67]. Despite their poor mechanical properties, they are good biomaterial for heart TE, as they have high biocompatibility, promote cell-binding and could biodegrade with no "additional treatment or modifications" [67].

Collagen is the most widely utilized natural polymer which is the most abundant ECM protein. It functions to guide biological processes, provide structural scaffolding, and tensile integrity [101]. Several kinds of literature have reported the use of various collagen types and their modifications in cardiac tissue repair [104-111].

Fibrin can be manipulated to create gels, microbeads, and hydrogels [85]. Likewise, biological molecules like the growth factors can be incorporated [112]. Fibrin glue can be used as a stand- 
328 alone therapy in cardiac tissue repair as it possesses intrinsic regenerative properties [113]. The

329 success of fibrin patch seeded with human embryonic stem cell-derived cardiac progenitor cells 330 (hESC-CPC) in non-human primate model [114] has resulted in its translation to the first case 331 report of the use of hESC-CPC in severe heart failure with an encouraging patient functional 332 outcome [115]. Other studies on fibrin have demonstrated its efficacy as a sealant after 333 intramyocardial injection [116]; for myocardial tissue repair when seeded with adult stem cells, 334 neonatal cardiac cell, and mesenchymal stem cells [117-119]; to form aortic valves in tissue 335 engineering [120].

336

337 Chitosan has been experimented in several literature as a biomaterial for cardiac regeneration [121, 338 122]. Overall, in cardiomyogenesis, many researchers have agreed on the fact that chitosan seems to be more effective when combined with other factors enhancing integration of stem cells into cardiac tissues [123].

Alginate, when used alone, has proven to have a remarkable effect on the function of heart models with myocardial infarction. Furthermore, seeding alginate with stem cells has proven to be more efficient in repair of the cardiac tissue [124-127].

The use of hyaluronic acid has been shown to be largely dependent on its molecular weight, and several kinds of literature have reported its successful use in cardiac tissue repair [128-131].

347 Evidence of gelatin scaffold placed subcutaneously, and/or on infarcted myocardium in adult rat hearts have shown a good survival of the graft, vessel formation and junctions with recipient rat heart cells [132]. Gelatin was reported to sustain neonatal rat cardiomyocyte tissue in vitro for three weeks [133]; supported the growth of human induced pluripotent stem cell (iPSC)-derived cardiomyocytes [133]; its hydrogel seeded with autologous human cardiac-derived stem cell and basic fibroblast growth factor (bFGF) effectively released bFGF for repair of ischemic cardiomyopathy [134]; and several other studies have shown the efficacy of gelatin as a scaffold for cardiomyogenesis when seeded with cells [135-138]. Fibrinogen/Thrombin-based Collagen Fleece (TachoCombo) have been successfully used to secure hemostasis and enhance complete 356 reconstruction of a large pulmonary artery defect in a canine model [139]. Hence, this biomaterial 
357 may be used in reconstruction of the low-pressure pulmonary vessels during a cardiac surgery for

358 a total anomalous pulmonary venous return or transposition of the great vessels.

359 Nevertheless, not all of these polymers can tune well for cardiac TE, and risk of inflammation still 360 exists [140].

361

362

\subsubsection{Native Extracellular Matrix as scaffold}

363

364

365

366

367

368

369

370

371

372

373

374

375

376

377

378

379

380

381

382

383

384

Native-specific ECM could be a category itself or part of natural polymers. ECM is collected from animal or donor tissue and processed for culturing cells [141]. Studies have shown that the ratio of native ECM in culture could play a key role in stem cells (SCs) enhancement, differentiation, survival, and phenotype [142]. Other studies have shown that contractible engineered heart patches cultured in ECM mixture and implanted in syngeneic Fischer 344 rats can vascularize, become innervated and survive up to 8 weeks in vivo [141].

Furthermore, ECM of decellularized and repopulated hearts and other organs are being used for drug testing [143]. An experiment on decellularized mouse hearts which were repopulated with human cells through coronary vessels exhibited myocardium, vessel-like structures and intracellular $\mathrm{Ca} 2+$ transients contracted spontaneously and responded as expected to various drug interventions [144]. It was concluded that heart "ECM could promote proliferation, specific cell differentiation and myofilament formation" [144]. The option of ECM for TE could help overcome the challenges faced using synthetic and other natural biomaterials to replace tissue, valves or organs [145].

\subsection{Scaffoldless Cell Sheet}

Another technique, which is independent of scaffolds, has been developed based on the cells' ability to connect via cell-to-cell junction proteins and create ECM [88]. The cells are cultured in normal conditions at $37^{\circ} \mathrm{C}$ in a temperature-responsive polymer cultures dish. When the culture temperature conditions change, the cells detach from the polymer culture dish as one cell sheet [88]. This technique was developed to avoid inflammatory reactions and fibrotic deposits in the area of graft where scaffold was placed following degradation [88]. A study has shown that 
385 contractile chick cardiomyocyte sheets could function effectively around rat thoracic aorta when 386 applied on host myocardium [81]. This cell sheet could synchronize within 1 hour of implantation 387 with the host tissue [81]. Similar results have been shown in 3D structures using several cell sheets 388 aiming to create a thick cardiac patch [146]. The number of sheets is limited, as more than three 389 exhibits poor vascularization. However, the combination of endothelial cells and cardiomyocytes 390 is being examined to promote vascularization before implantation [88]. Table 3 summarizes the 391 pros and cons of the various materials and biomaterials used in tissue engineering. 


\subsection{Stem Cells for tissue engineering}

396

397

398

399

400

401

402

403

404

405

406

407

408

409

410

411

412

413

414

415

416

417

418

419

420

An equally important point in choosing a suitable biomaterial, scaffold or scaffoldless cell sheet, is the choice of the most appropriate cell types suitable for the TE. Stem cells (SCs) as a known cell source possesses the ability to differentiate toward Cardiac Muscle Cells/cardiomyocytes (CMCs), smooth muscle cells (SMCs) and endothelial cells (ECs), can regenerate cardiac tissue. Based on these properties, they play a key role in TE field. The currently used SCs in TE are summarized in Table 4.

\subsection{Embryonic Stem Cells}

Embryonic stem cells (ESCs) are one of the cell sources which are used in TE approaches. ESCs are derived from the inner cell mass of preimplantation blastocyst [147]. They can differentiate into all different cell types of three germ layers. Human ESC (hESC) could be a good candidate for cardiac tissue engineering. In a study conducted by Landry et al., hESC-derived cardiomyocytes (hESC-CMC) showed very good phenotype including myofibril alignment, density, morphology, contractile performance and gene expression profile which, however, was only confirmed after 80-120 days in vitro culture [148]. Various groups apart from Landry and colleagues conducted studies to confirm the successful differentiation of ESC to cardiomyocytes as presented in a review by Boheler and colleagues in 2002 [149]. Duan et al. investigated how native cardiac ECM could affect hESC differentiation. This group processed porcine hearts to collect digested cardiac ECM which then mixed with collagen to create a hydrogel for cell cultivation purposes. The cultured hESCs on biomaterials comprised of $75 \%$ native cardiac porcine ECM and 25\% hydrogel with no additional growth factors have shown a great differentiation with cardiac troponin $\mathrm{T}$ expression and contractile behavior, compared to the hydrogel with a smaller ratio of native ECM [142]. Based on various studies, ESCs could be a good option for cardiac TE [141]. Additionally, some factors such as ethical concerns, provoked immunogenicity, and risk of tumorigenesis make the ESCs a very controversial choice of cell source for TE [74]. 


\section{$421 \quad 5.2$ Induced Pluripotent Stem Cells}

422 Another type of SCs which are used in TE is induced pluripotent stem cells (iPSCs). The iPSCs

423 are somatic cells which are reprogrammed to behave like ESC and show the same properties. The

424 iPSCs can differentiate into all three germ layers $[150,151]$. Takahashi and his group were the

425 first groups who were able to reprogram the somatic adult cells like fibroblasts to iPSCs using viral

426 vectors to introduce four key factors OCT4, SOX2, c-Myc, and KFL-4 to fibroblasts [150]. This

427 method was used to reprogram fibroblasts to embryonic-like cells and from this state differentiate

428 them into a relevant type of cells [150]. Ludry et al. have also shown that human iPSC-derived

429 cardiomyocytes (hiPSC-CMCs) present the same characteristics as hESC-derived cardiomyocytes

430 in long-term in vitro culture [148]. $\mathrm{Lu}$ and colleagues presented the successful repopulation of 431 decellularized cadaveric mouse heart with hiPSC-derived multipotential cardiovascular 432 progenitors [148]. They also demonstrate that the heart ECM promotes proliferation, 433 differentiation and myofilament formation of CMs from the repopulated hiPSC-derived cells. 434 Furthermore, they have checked the electrical coupling of these cells and also examined the constructive ability of repopulated heart using electrocardiogram which presented arrhythmia. Lu et al. have further examined the effects of pharmacological agents on repopulated heart and observed remarkable responses [141]. This model is explored as an option to personalized medicine concerning drug testing/discovery [141, 152]. Specifically, for CHD which presents such a variety of profiles, individual patient-specific human models' development could help to understand how each patient would respond to existing pharmaceutical treatments. Even though it may not be possible to create actual organ heart models with individual clinical features of the disease [153].

Nonetheless, like ESC, iPSC has demonstrated tumorigenesis [74]. The group of Leda and colleagues showed a direct transdifferentiation of fibroblasts to functional cardiomyocytes using three key factors, Gata4, Mef2c, and Tbx5, within a very short time and suggested that direct reprogramming could reduce the risk of tumorigenesis [154]. Still, using viral vectors for reprogramming procedure is problematic and involves various risks [74]. Therefore, today more different ways for iPSC production are being used and investigated to find out safer and more effective alternatives for this reprogramming procedure $[21,155]$. In the event this problem is solved, iPSC could be the safest type of cell sources for TE as they will not provoke any immune- 
451 response and cell harvesting procedure to produce iPSCs is not life-threatening for the patients.

452 Moreover, iPSC raises less ethical concerns in comparison to ESC or fetal SC.

453

454

\subsection{Prenatal, Perinatal, and Postnatal Stem Cells}

455 Prenatal, perinatal and postnatal SCs are other cell sources used in TE, which include chorionic 456 villi derived multipotent SCs, amniotic fluid-derived SCs (AFSCs), umbilical cord blood derived457 endothelial progenitor cells (UCB-EPCs) and umbilical cord- or cord blood-derived- multipotent 458 SCs [156]. UCB progenitors, like endothelial progenitor cells (EPCs), have distinctive 459 proliferative properties in comparison to other cells sources [157]. This category of SCs is 460 exceptionally important as the child's own SCs could be used for heart TE, for CHD patients who 461 are diagnosed before birth. Immunogenicity or an additional procedure to harvest autologous SCs 462 from the infant or child could be avoided in this procedure. Furthermore, it has been proven that 463 AFSCs do not form teratomas in contrast to ESCs and iPSCs [158]. All categories of these cells 464 have been investigated with remarkable results on engineered valves and vascular grafts [156, 159465 163]. This type of SCs is not applicable to adults who have been diagnosed later in life with CHD.

\subsection{Adult Stem Cells}

\subsubsection{Bone Marrow-derived Stem cells}

469

470

471

472

473

474

475

476

477

Apart from UCB, EPCs can be found in the peripheral blood (PB-EPCs) and bone marrow (BMEPCs) of adults $[164,165]$. However, bone marrow is a richer source of EPCs in comparison to peripheral blood. In 1997, Asahara et al. identified the CD34+ mononuclear hematopoietic progenitor cells in the peripheral blood which in vitro presented endothelial-like characteristics [164]. The EPCs which are originated from BM considered to play a crucial role in endothelial repair, and they have been suggested for treatment of ischemia patients and vascular TE with very encouraging results $[158,160,165,166]$. A successful complete endothelium regeneration of decellularized canine carotid arteries has been reported in animal studies using PB-EPCs [167]. In addition to vascular TE, the EPCs have been assessed for tissue-engineered heart valves [168]. 
478 Bone marrow derived EPCs are greatly involved in de novo vessel formation and 479 neovascularization in pathological conditions like ischemia and cancer [164]. Similar applications 480 to PB-EPCs and prenatal EPCs have been recorded for vascular graft in the congenital heart 481 surgery using bone marrow-derived stem cells [169]. Mirensky and colleagues used sheets of non482 woven PGA mesh as a scaffold to create vascular graft in combination with human bone marrow 483 mononuclear cells (BM-MNCs). The results were very encouraging as no aneurysm or thrombotic 484 incidence were reported, despite the absence of anticoagulants. This group suggests this method 485 as a suitable vascular treatment for CHD based on their results from 6 weeks follow up after graft 486 487 implantation, which has shown signs of degradation, and it was fully accommodated by the host's cells [169]. Nonetheless, the host mice were at full-growth which makes it questionable how successful this application could be in a developing animal model. Interestingly only one week after implantation no human BM-MNCs were detected, which suggests that BM-MNCs play a paracrine role rather than cell replacement [165]. More studies have reported similar results with the same conclusion [74,170]. Furthermore, an investigation on 25 young patients under 30 years old who underwent extracardiac total cardiopulmonary connection with BM-MNCs engineered vascular graft has also presented convincing results. A long-term patient follow-up has shown zero deaths in relation to the implanted grafts, no thromboembolic, hemorrhagic, or infectious complications, however, 6 of them developed grafts stenosis which was treated successfully [74]. Despite the encouraging results with BM-MNCs, BM-MSCs still present more advantages. These advantages are, for example, their ability to differentiate into a variety of cell types even progenitor cells; relatively easy procedure for their collection, isolation, storage, and proliferation; presenting a similar phenotype to the valve cells; present anti-thrombogenic properties; and their immunogenicity is manageable [89, 145]. In a comparative study, Vincentelli et al. examined short- and long-term characteristics of the porcine decellularized scaffold which were processed with in-situ injections of BM-MNCs and BM-MSCs, before transplanting in a lamb of animal models [171]. Short-term results did not show any significant differences. However, the 4 months (long-term) follow up has shown a significant decrease of transvalvular and distal gradients, more inflammatory reaction, more structural deterioration as well as calcification, and a thick fibrous group were significantly different from the BM-MSCs group [171]. 
509

510

511

512

513

514

515

516

517

518

519

520

521

522

523

524

525

526

527

528

529

530

531

532

533

534

535

536

537

\subsubsection{Cardiac Progenitor Cells}

Cardiac progenitor cells (CPCs) or also known as Cardiac Stem Cells (CSCs) are a type of cells which are found in the adult heart and express stem cell factor receptor kinase c-kit + , also shown to be negative for the markers of blood/endothelial cell lineage [17]. CPCs have only been in the spotlight for about 15 years now with the credit given to Beltrami and colleagues as they demonstrated the self-renewing and multipotent characteristics of these cells; differentiating into all three different cardiogenic cell types which are cardiomyocytes, smooth muscle cells and endothelial cells [17]. More recently, a study carried out by Vicinanza and colleagues helped to lay to rest the controversies about c-kit+ cardiac cells by demonstrating that only a small fraction of the c-kit+ adult cardiac stem cells possess the tissue-specific progenitor properties [172]. The study was carried out in adult Wistar rats in which an experimental acute myocardial infarction (MI) was induced and the border of the infarcts were injected with GFP+c-kit + for the first group, "GFP-expressing CD45-c-kit+ CSCs (CSC ${ }^{\mathrm{GFP}}$ )" for the second group, and the placebo group were injected with PBS. The study showed that CSCGFP only significantly reduced apoptosis and hypertrophy of the cardiomyocytes, it also significantly reduced scarring and improved ventricular functions [172]. The study further demonstrated that about $10 \%$ of the overall c-kit + cardiac cells are CD45-c-kit+, and only about $10 \%$ of these are clonogenic and multipotent. Therefore, it was inferred that only about $1-2 \%$ of the total c-kit + myocardial cells have a demonstrable multipotent CSC phenotype [172]. These c-kit+CD45-(deletion of which also renders the cells CD31-, CD34-) CPCs were also shown to express to some degree Sca-1, Abcg2, CD105, CD166, PDGFR- $\alpha$, Flk1, ROR2, CD13, and CD90 [172]. The number of CPCs have however been shown to be significantly higher in neonates but dramatically decreases after the age of $2[71,173]$. Thus, these CPCs in combination with a suitable scaffold, could be the answer to treat a number of CHD, as CPCs could be collected during palliative surgery or via endomyocardial biopsy $[19,64]$.

The potential SCs and biomaterials for TE in CHDs are represented in the figure 1 below. Also, the figure 2 below shows the promising strategies for the treatment of CHDs.

\section{Table 4 Scaffolds and SCs used for TE in some study models}


539 Figure 1: This schema represents the different types of stems that can be used on the biomaterial 540 backbone (depicted as the background characters) for cardiovascular Tissue Engineering (TE). A) 541 Induced pluripotent stem cells (iPSCs) derived from fibroblast. B) Prenatal, Perinatal, and 542 Postnatal Stem cells (PPPSCs) are derived from amniotic fluid, umbilical cord, and chorionic villi. 543 C) Bone Marrow Stem Cells (BMSCs) such endothelial progenitor cells (EPCs) and Mesenchymal 544 stem cells (MSCs) can easily be isolated from the bone marrow. D) Cardiac progenitor cells 545 (CPCs) can be harvested during palliative surgery or endomyocardial biopsy. E) Embryonic stem 546 cells (ESCs) derived from the inner cell mass of the blastocyst

Figure 2 : The schematic diagram represents the potential of Stem Cells (SCs) and Tissue Engineering (TE) for corrective surgical treatment of infants as well as adolescent patients with

552 Congenital Heart Disease (CHD). Various sources for Stem Cells (SCs) are presented here as 553 alternatives to harvesting the appropriate Stem Cells (SCs) which can be used to seed on clinically 554 certified biomaterial scaffolds for reconstructing functional cardiac tissue- engineered grafts. 555 These grafts could be implanted via the corrective surgery into the heart of infants and adolescent patients with Congenital Heart Disease (CHD) for definitive correction of cardiac defects. This optimized cardiac-tissue engineered grafts should have potential to grow in parallel with the child, while are lacking any tumorigenicity, immunogenicity, thrombogenicity, calcification, and other risk factors.

\subsection{STANDPOINT}

562 Due to the high number of patients as well as newborns who are suffering from CHD and also high 563 costs of their implications, it is necessary and vital to making intensive research for finding an effective treatment for CHD patients. Stem cell research has shown remarkable results in all kinds

565 of tissue engineering including skin [174], cartilage [175], vascular [176], ocular [177] and cardiac 566 tissues $[82,87,178,179]$. 
568 The importance of engineered cardiac tissue lies in the fact that synthetic non-degradable materials 569 cannot adjust to the patient's developing body. A number of patients who suffer from CHD are 570 adults, and they are more suitable for this type of therapies. However, many patients with severe 571 CHD are infants and children whose body is constantly developing. Although, various synthetic 572 and natural biodegradable biomaterials have been used so far which have shown good results, the 573 one with the best degradation rate is yet to be found. There are various complications related to 574 existing surgical treatments and scaffolds which cannot be ignored. Calcification, inflammatory 575 reaction and life-long anticoagulants treatment are the most important known complications for 576 the conventional methods of CHD treatment $[14,70]$. The complexity of CHD makes TE possibly 577 the most suitable solution for treatment of patients with CHD.

\subsection{CONCLUSION}

581

582

583

584

585

586

587

588

589

590

591

592

593

594

The replacement or correction of a malformation in a complex system like the cardiovascular system could only be successful with tissues which can mimic the native heart and vascular tissues. SCs have opened the door to such treatments. The best SC candidates and biomaterials are yet to be identified, despite the encouraging results. All different types of SCs which have been investigated so far still present some disadvantages. Extensive research would be required to enable deeper understanding, solve drawbacks, and promote SCs use for tissue engineering in the future. All the efforts channeled at obtaining proper legal regulation for using SCs, developing new technologies for scaffold production as well as scaffoldless techniques, developing faster and safer methods for producing patient-specific iPSCs, and research into the effectiveness of SCs in $\mathrm{TE}$ for treatment of $\mathrm{CHD}$, predicts a very positive future for patients, researchers and surgeons.

\section{Acknowledgement:}


595 The authors wish to appreciate Professor Costanza Emanueli, Professor of Cardiovascular 596 Medicine, School of Clinical Sciences, University of Bristol and the Bristol Heart Institute, and 597 Professor Massimo Caputo, Professor of Congenital Heart Disease and Consultant in 598 Cardiothoracic Surgery, University of the Bristol and the Bristol Heart Institute, for assigning this 599 work. The authors also wish to appreciate the contributions of Precious Anthony, Favour Anthony, 600 and David Otohinoyi at the All Saints University School of Medicine.

601 
602

603 Reference

604

605

606

607

1. National Congenital Heart Disease Audit Report 2012-2015. (2016) London: National Institute for Cardiovascular Outcomes Research. Retrieved from; https://nicor5.nicor.org.uk/chd/an_paeds.nsf/vwContent/home?Opendocument

608

609

610

611

612

613

614

615

616

617

618

619

620

621

622

623

624

625

626

2. British Heart Foundation. (2016). Retrieved from: www.bhf.org.uk: https://www.bhf.org.uk/research/heartstatistics

3. Okudo M, Benson LD. (2001) Intravascular and intracardiac stents used in congenital heart disease. Current Opinions in Cardiology, 16(2): 84-91.

4. Gilboa SM, Devine OJ, Kucik JE, Oster ME, Riehle-Colarusso T, Nembhard WN, Xu P, Correa A, Jenkins K, Marelli AJ. (2016) Congenital Heart Defects in the United States: Estimating the Magnitude of the Affected Population in 2010. Circulation 134(2):101-9. doi: 608 10.1161/CIRCULATIONAHA.115.019307.

5. Dolk H, Loane M, Garne E. (2011). Congenital Heart Defects in Europe: Prevalence and PerinatalMortality 2000-2005. Circulation 123(8):841-9. doi:10.1161/CIRCULATIONAHA.110.958405

6. Hoffman JI, Kaplan S. (2002). The incidence of congenital heart disease. Journal of the American College of Cardiology, 39 (12): 1890-1900, https://doi.org/10.1016/S0735-1097(02)01886-7

7. van der Linde D, Konings EE, Slager MA, Witsenburg M, Helbing WA, Takkenberg JJ, RoosHesselink JW. (2011) Birth Prevalence of Congenital Heart Disease Worldwide: A Systematic Review and Meta-Analysis, Journal of the American College of Cardiology, 58(21): 2241 2247.https://doi.org/10.1016/j.jacc.2011.08.025

8. NHS England. (2015). Proposed National Standards and Service Specifications for Congenital Heart Disease Services: Financial Impact Analysis. London: NHS England. https://www.england.nhs.uk/wp-content/uploads/2015/06/chd-finance.pdf

627

9. Lundberg, M. (2013) Cardiovascular Tissue Engineering Research Support at the National Heart, Lung, and Blood Institute. Circulation Research, 112(8): 1097-1103. doi:10.1161/CIRCRESAHA.112.300638

630

631

632

633

634

10. Nayak K, Chandra G S N, Shetty R, Narayan PK. (2016) Evaluation of fetal echocardiography as a routine antenatal screening tool for detection of congenital heart disease. Cardiovascular Diagnosis and Therapy, 6(1): 44-49. doi:10.3978/j.issn.2223-3652.2015.12.01

11. Sun R., Liu M., Lu L., Zheng Y., Zhang P. (2015) Congenital Heart Disease: Causes, Diagnosis, Symptoms, and Treatments. Cell Biochemistry and Biophysics, 72(3): 857-860.

635

636

637

638

12. Durant, M. (2018). The Ethiopian's Leg : Saint Lucy. [online] Saint-lucy.com. Available at: https://saintlucy.com/slider/the-ethiopians-leg/ [Accessed 7 Jul. 2018].

13. Finch, J. (2011). The ancient origins of prosthetic medicine. The Lancet, 377(9765), pp.548-549.

639

14. Zilla P, Brink J, Human P, Bezuidenhout D. (2008) Prosthetic Heart Valves: Catering for the few. Biomaterials, 
640

641

642

643

644

645

646

647

648

649

650

651

652

653

654

655

656

657

658

659

660

661

662

663

664

665

666

667

668

669

670

671

672

673

674

675

676

29(4): $385-406$.

15. Gott VL, Alejo DE, Cameron DE. (2003) Mechanical heart valves: 50 years of evolution. The Annals of Thoracic Surgery, 76(6): S2230-S2239.

16. Sun R, Liu M, Lu L, Zheng Y, Zhang P. (2003) Thoracic Surgery Directors Association Award. Bone marrow as a cell source for tissue engineering heart valves. The Annals of Thoracic Surgery, 75(3): 761-767.

17. Beltrami AP, Barlucchi L, Torella D, Baker M, Limana F, Chimenti S, Kasahara H, Rota M, Musso E, Urbanek K, Leri A, Kajstura J, Nadal-Ginard B, Anversa P. (2003) Adult Cardiac Stem Cells Are Multipotent and Support Myocardial Regeneration. Cell, 114(6): 763-776. https://doi.org/10.1016/S0092-8674(03)00687-1

18. Rupp S, Schranz D. (2015) Cardiac Regeneration in Children. Pediatric Cardiology, 36(4): 713-718.

19. Saxena, A. K. (2010) Congenital Anomalies of Soft Tissues: Birth Defects Depending on Tissue Engineering Solutions and Present Advances in Regenerative Medicine. Tissue Engineering, 16(5): 455-466. doi: 10.1089/ten.TEB.2009.0700.

20. Ebert AD, Diecke S, Chen IY, Wu JC. (2015) Reprogramming and transdifferentiation for cardiovascular development and regenerative medicine: where do we stand? Molecular Medicine, 7(9), 1090-1103. doi: 10.15252/emmm.201504395.

21. Tarui S, Sano S, and Oh H. (2014) Stem cell therapies in patients with single ventricle physiology. Methodist Debakey Cardiovascular Journal, 10(2): 77-81.

22. Fakoya AOJ. (2017) New Delivery Systems of Stem Cells for Vascular Regeneration in Ischemia. Frontiers in Cardiovascular Medicine, 4:7. doi: 10.3389/fcvm.2017.00007.

23. Feric NT, Radisic M. (2016) Strategies and Challenges to Myocardial Replacement Therapy. Stem Cells Transplantation Medicine, 17(6): 410-416. doi: 10.3390/ijms17060982.

24. Penny DJ, Vick GW (2011) Ventricular Septal Defect. The Lancet, 377(9771):1103-12. doi: 10.1016/S0140-6736(10)61339-6.

25. Boening A, Scheewe J, Heine K, Hedderich J, Regensburger D, Kramer HH, Cremer J. (2002) Long-term results after surgical correction of atrioventricular septal defects. European Journal of Cardio-Thoracic Surgery, 22(2), p167-73.

26. Apitz C, Webb GD, Redington A. (2009) Tetralogy of Fallot, .The Lancet, 374(9699), 1462-1471, https://doi.org/10.1016/S0140-6736(09)60657-7

27. Freeman R, Otto C. (2005) Spectrum of Calcific Aortic Valve Disease Pathogenesis, Disease Progression, and Treatment Strategies. Circulation, 111(24), 3316-3326. doi: 10.1161/CIRCULATIONAHA.104.486738

28. Tanya Smith, Cha Rajakaruna, Massimo Caputo, and Costanza Emanueli. (2015) MicroRNAs in congenital heart disease. Annals of Translational Medicine 21: 333, doi: 10.3978/j.issn.23055839.2015.12.25

29. Medscape. (2015, August 19). Retrieved from http://emedicine.medscape.com/article/894095- 
677

678

679

680

681

682

683

684

685

686

687

688

689

690

691

692

693

694

695

696

697

698

699

700

701

702

703

704

705

706

707

708

709

710

711

712

713

714

715

overview:

30. Pedra, C., Haddad, J., Pedra, S., Peirone, A., Pilla, C. and Marin-Neto, J. (2009). Paediatric and congenital heart disease in South America: an overview. Heart, 95(17), pp.1385-1392.

31. CDC (2018). Atrial Septal Defect Facts $\mid$ Congenital Heart Defects $|N C B D D D| C D C$. [online] Centers for Disease Control and Prevention. Available at:

https://www.cdc.gov/ncbddd/heartdefects/atrialseptaldefect.html [Accessed 29 May 2018].

32. MayoClinic (2018). Atrial septal defect (ASD) - Diagnosis and treatment - Mayo Clinic. [online] Mayoclinic.org. Available at: https://www.mayoclinic.org/diseases-conditions/atrial-septal-defect/diagnosistreatment/drc-20369720 [Accessed 25 Jan. 2018].

33. Krasuski, R. and Bashore, T. (2016). Congenital Heart Disease Epidemiology in the United States. Circulation, 134(2), pp.110-113.

34. van der Linde, D., Konings, E., Slager, M., Witsenburg, M., Helbing, W., Takkenberg, J. and Roos-Hesselink, J. (2011). Birth Prevalence of Congenital Heart Disease Worldwide. Journal of the American College of Cardiology, 58(21), pp.2241-2247.

35. NHS (2018). Symptoms. [online] nhs.uk. Available at: https://www.nhs.uk/conditions/congenital-heartdisease/symptoms/ [Accessed 5 Jun. 2015].

36. Calderón-Colmenero, J., Cervantes-Salazar, J., Curi-Curi, P. and Ramírez-Marroquín, S. (2013). Congenital Heart Disease in Mexico. World Journal for Pediatric and Congenital Heart Surgery, 4(2), pp.165-171.

37. HeartKids (2018). Congenital Heart Disease - Heartkids site. [online] Heartkids.org.au. Available at: https://www.heartkids.org.au/congenital-heart-disease [Accessed 5 Jun. 2011].

38. Postoev, V., Talykova, L. and Vaktskjold, A. (2014). Epidemiology of cardiovascular malformations among newborns in Monchegorsk (north-west Russia): a register-based study. Journal of Public Health Research, 3(2):270.

39. Patnana, S. and Turner, D. (2018). Pediatric Hypoplastic Left Heart Syndrome: Background,Pathophysiology, Etiology. [online] Emedicine.medscape.com. Available at: https://emedicine.medscape.com/article/890196overview [Accessed 7 Jan. 2017].

40. van der Linde, D., Konings, E., Slager, M., Witsenburg, M., Helbing, W., Takkenberg, J. and Roos-Hesselink, J. (2011). Birth Prevalence of Congenital Heart Disease Worldwide. Journal of the American College of Cardiology, 58(21), pp.2241-2247.

41. Zühlke, L., Mirabel, M. and Marijon, E. (2013). Congenital heart disease and rheumatic heart disease in Africa: recent advances and current priorities. Heart, 99(21), pp.1554-1561.

42. Canadian Heart Alliance (2018). Facts and issues. [online] Canadian Congenital Heart Alliance. Available at: https://www.cchaforlife.org/facts-issues [Accessed 6 Jun. 2018].

43. CDC (2018). Hypoplastic Left Heart Syndrome Facts | Congenital Heart Defects. [online] Centers for Disease Control and Prevention. Available at: https://www.cdc.gov/ncbddd/heartdefects/hlhs.html [Accessed 8 Nov. 2016].

44. AHA (2018). Atrial Septal Defect (ASD). [online] Heart.org. Available at: http://www.heart.org/HEARTORG/Conditions/CongenitalHeartDefects/AboutCongenitalHeartDefects/AtrialSeptal-Defect-ASD_UCM_307021_Article.jsp [Accessed 19 Jan. 2018]. 
716

717

718

719

720

721

722

723

724

725

726

727

728

729

730

731

732

733

734

735

736

737

738

739

740

741

742

743

744

745

746

747

748

749

750

751

752

753

754

45. Mai, C., Riehle-Colarusso, T., O'Halloran, A., Cragan, J., Olney, R., Lin, A., Feldkamp, M., Botto, L., Rickard, R., Anderka, M., Ethen, M., Stanton, C., Ehrhardt, J. and Canfield, M. (2012). Selected birth defects data from population-based birth defects surveillance programs in the United States, 2005-2009: Featuring critical congenital heart defects targeted for pulse oximetry screening. Birth Defects Research Part A: Clinical and Molecular Teratology, 94(12), pp.970-983.

46. MayoClinic (2018). Tricuspid atresia - Symptoms and causes. [online] Mayo Clinic. Available at: https://www.mayoclinic.org/diseases-conditions/tricuspid-atresia/symptoms-causes/syc-20368392 [Accessed 8 Mar. 2018].

47. MayoClinic (2018). Tetralogy of Fallot - Symptoms and causes. [online] Mayo Clinic. Available at: https://www.mayoclinic.org/diseases-conditions/tetralogy-of-fallot/symptoms-causes/syc-20353477 [Accessed 9 Mar. 2018].

48. Baffa, J. (2018). Tetralogy of Fallot - Pediatrics - MSD Manual Professional Edition. [online] MSD Manual Professional Edition. Available at: https://www.merckmanuals.com/professional/pediatrics/congenitalcardiovascular-anomalies/tetralogy-of-fallot [Accessed 22 Nov. 2016].

49. Northwestern Medicine (2018). Bicuspid Aortic Valve Symptoms. [online] Northwestern Medicine. Available at: https://www.nm.org/conditions-and-care-areas/cardiovascular-care/center-for-heart-valvedisease/bicuspid-aortic-valve/symptoms [Accessed 7 Jun. 2018].

50. MayoClinic (2018). Bicuspid aortic valve - Overview - Mayo Clinic. [online] Mayoclinic.org. Available at: https://www.mayoclinic.org/diseases-conditions/bicuspid-aortic-valve/cdc-20385577 [Accessed 7 Jun. 2018].

51. MayoClinic (2018). Patent ductus arteriosus (PDA) - Symptoms and causes. [online] Mayo Clinic. Available at: https://www.mayoclinic.org/diseases-conditions/patent-ductus-arteriosus/symptoms-causes/syc-20376145 [Accessed 25 Jan. 2018].

52. Cleveland Clinic (2018). Patent Ductus Arteriosus (PDA) Treatment Options | Cleveland Clinic. [online] Cleveland Clinic. Available at: https://my.clevelandclinic.org/health/diseases/17325-patent-ductus-arteriosuspda/treatment-options [Accessed 7 Jun. 2018].

53. MayoClinic (2018). Pulmonary valve stenosis - Symptoms and causes. [online] Mayo Clinic. Available at: https://www.mayoclinic.org/diseases-conditions/pulmonary-valve-stenosis/symptoms-causes/syc-20377034 [Accessed 8 Jun. 2018].

54. Spicer, D., Hsu, H., Co-Vu, J., Anderson, R. and Fricker, F. (2014). Ventricular septal defect. Orphanet Journal of Rare Diseases, 9(144),pp1-16.

55. Carminati, M., Butera, G., Chessa, M., De Giovanni, J., Fisher, G., Gewillig, M., Peuster, M., Piechaud, J., Santoro, G., Sievert, H., Spadoni, I. and Walsh, K. (2007). Transcatheter closure of congenital ventricular septal defects: results of the European Registry. European Heart Journal, 28(19), pp.2361-2368.

56. Minette, M. and Sahn, D. (2006). Ventricular Septal Defects. Circulation, 114(20), pp.2190-2197.

57. NIH (2018). Hirschsprung Disease | NIDDK. [online] National Institute of Diabetes and Digestive and Kidney Diseases. Available at: https://www.niddk.nih.gov/health-information/digestive-diseases/hirschsprung-disease [Accessed 7 Jun. 2018].

58. Martins, P. and Castela, E. (2018). Transposition of the great arteries. [online] BMC. Available at: https://ojrd.biomedcentral.com/articles/10.1186/1750-1172-3-27 [Accessed 8 Jun. 2018]. 
755

756

757

758

759

760

761

762

763

764

765

766

767

768

769

770

771

772

773

774

775

776

777

778

779

780

781

782

783

784

785

786

787

788

789

790

791

792

793

59. Cincinnati Children Health (2018). Hirschsprung Disease in Infants \& Children | Diagnosis \& Treatment. [online] Cincinnatichildrens.org. Available at: https://www.cincinnatichildrens.org/health/h/hirschsprung [Accessed 5 Jun. 2018].

60. Khan, A., Ramsey, K., Ballard, C., Armstrong, E., Burchill, L., Menashe, V., Pantely, G. and Broberg, C. (2018). Limited Accuracy of Administrative Data for the Identification and Classification of Adult Congenital Heart Disease. Journal of the American Heart Association, 7(2), p.e007378.

61. Safi, L., Liberthson, R. and Bhatt, A. (2016). Current Management of Ebstein's Anomaly in the Adult. Current Treatment Options in Cardiovascular Medicine, 18(9).

62. Skybchyk, V. and Melen, Y. (2017). Calcific Aortic Valve Stenosis: Current Approaches to the Diagnosis, Medical and Surgical Treatment. HYPERTENSION, 0(6.50), pp.74-80.

63. Johnson MC, Swanson PE, Johnson DC, Schuessler RB, Cox JL. (1998), An experimental model of small intestinal submucosa as a growing vascular graft. Journal of Thoracic and Cardiovascular Surgery, 116(5), 805811.

64. Torok, R. (2015). Coarctation of the aorta: Management from infancy to adulthood. World Journal of Cardiology, 7(11), p.765.

65. Dodson, R. (2014). Comprehensive surgical management of congenital heart disease. 2 nd ed. Florida: CRC press.

66. Homann M, Haehnel JC, Mendler N, Paek SU, Holper K, Meisner H, Lange R. (2000) Reconstruction of the RVOT with valved biological conduits: 25 years' experience with allografts and xenografts. European Journal of Cardio-Thoracic Surgery, 17(6), 624-630. https://doi.org/10.1016/S1010-7940(00)00414-0

67. Files MD, Boucek RJ. (2012). 'Shovel-Ready' applications of stem cell advances for pediatric heart disease. Current Opinion In Pediatric, 24(5), 577-583, doi: 10.1097/MOP.0b013e328357a4cf.

68. Kaiser N, Coulombe K. (2016) Physiological inspired cardiac scaffolds for tailored in vivo function and heart regeneration. Biomedical Materials, 10(3): 034003. doi:10.1088/1748$6041 / 10 / 3 / 034003$

69. Rienks M, Papageorgiou A, Frangogiannis N, Heymans S. (2014) Myocardial Extracellular Matrix: An Ever-Changing and Diverse Entity. Circulation Research. 114(5):872-888. https://doi.org/10.1161/CIRCRESAHA.114.302533

70. Brown L. (2005) Cardiac extracellular matrix: a dynamic entity. AJP: Heart and Circulatory Physiology. 289(3), H973-H974. https://doi.org/10.1152/ajpheart.00443.2005

71. Chaikof EL. (2007), The Development of Prosthetic Heart Valve: Lessons in Form and Function. The New England Journal of Medicine, 357:1368-1371. doi: 10.1056/NEJMp078175

72. Ratner, B., Hoffman, A., Schoen, F. and Lemons, J. (2004). Biomaterials science. 2nd ed. Amsterdam: Elsevier Academic Press.

73. Hibino N, McGillicuddy E, Matsumura G, Ichihara Y, Naito Y, Breuer C, Shinoka T. (2010) Late- term results of tissue-engineered vascular grafts in humans. The Journal of Thoracic and Cardiovascular Surgery, 139(2), 431-436. 
794

795

796

797

798

799

800

801

802

803

804

805

806

807

808

809

810

811

812

813

814

815

816

817

818

819

820

821

822

823

824

825

826

827

828

829

830

831

832

833

834
74. Schmidt CE, Baier JM. (2010) Acellular vascular tissues: natural biomaterials for tissue repair and tissue engineering. Biomaterials, 21 (22), 2215-2231.

75. Kurobe H, Maxfield MW, Breuer CK, Shinoka T. (2012) Concise review: tissue-engineered vascular grafts for cardiac surgery: past, present, and future. Stem Cells Translational Medicine, 1(7):566-71. doi: 10.5966/sctm.2012-0044.

76. Johnson MC, Swanson PE, Johnson DC, Schuessler RB, Cox JL. (1998), An experimental model of small intestinal submucosa as a growing vascular graft. Journal of Thoracic and Cardiovascular Surgery, 116(5), 805-811.

77. Ruiz CE, Iemura M, Medie S, Varga P, Van Alstine WG, Mack S, Deligio A, Fearnot N, Beier UH, Pavcnik D, Hijazi ZM, Kiupel M. (2005) Transcatheter placement of a low-profile 4biodegradable pulmonary valve made of small intestinal submucosa: a long-term study in a swine model. Journal of Thoracic and Cardiovascular Surgery. 130(2), 477-484. 706https://doi.org/10.1016/j.jtcvs.2005.04.008

78. Wainwright JM, Hashizume R, Fujimoto KL, Remlinger NT, Pesyna C, Wagner WR, Tobita K, Gilbert TW, Badylak SF. (2012) Right ventricular outflow tract repair with a cardiac biologic scaffold. Cells Tissues Organs 195(1-2). 159-70. https://doi.org/10.1159/000331400

79. Scholl FB, Boucek MM, Chan K-C, Valdes-Cruz L, Perryman R. (2010) Preliminary experience with cardiac reconstruction using decellularized porcine extracellular matrix scaffold: human applications in congenital heart disease. World Journal of Pediatric and Congenital Heart Surgery, 1(1) $713 \quad 132-136$.

80. Quarti A, Nardone S, Colaneri M, Santoro G, Pozzi M. (2011) Preliminary experience in the use of an extracellular matrix to repair congenital heart diseases. Interactive CardioVascular and Thoracic Surgery 13(6), 569-572, https://doi.org/10.1510/icvts.2011.280016.

81. Witt RG, Raff G, Van Gundy J, Rodgers-Ohlau M, Si MS. (2013) Short-term experience of porcine small intestinal submucosa patches in paediatric cardiovascular surgery. European Journal of Cardiothoracic Surgery 44(1), 72-76, https://doi.org/10.1093/ejcts/ezs638

82. Miyagawa S, Roth M, Saito A, Sawa Y, Kostin S. (2011) Tissue-Engineered Cardiac Constructs for Cardiac Repair. The Annals of Thoracic Surgery, 91(1), 320-329. https://doi.org/10.1016/j.athoracsur.2010.09.080

83. Avolio, E., Caputo, M., Madeddu, P. (2015) Stem cell therapy and tissue engineering for correction of congenital heart disease. Frontiers in Cell and Developmental Biology 3(39), 1-17. https://doi.org/10.3389/fcell.2015.00039

84. Williams, D. (2004) Benefit and risk in tissue engineering. Materials Today, 7(5), 24-29. doi: $10.1016 / \mathrm{S} 1369-7021(04) 00232-9$

85. Zhao G, Zhang X, Lu TJ, Xu F. (2015) Recent Advances in Electrospun Nanofibrous Scaffolds for Cardiac Tissue Engineering. Advanced Functional Materials. 9(8): 5726-5738. doi: $10.3390 / \mathrm{ma} 9080614$

86. Maeda K, Tiwari-Pandey R, Ruel M, Suuronen E. (2015) Matrix Therapies for Cell Support and Cardiac Repair. In: Suuronen E, Ruel M, ed. by. Biomaterials for Cardiac Regeneration. London: Springer; p. 117-146. 
87. Sugiura T, Matsumura G, Miyamoto S, Miyachi H, Breuer CK, Shinoka T. (2018) Tissue-engineered vascular in children with congenital heart disease: Intermediate term followup. Seminars in Thoracic and Cardiovascular surgery. doi: 10.1053/j.semtcvs.2018.02.002.

88. Carrier RL, Papadaki M, Rupnick M, Schoen FJ, Bursac N, Langer R. (1999) Cardiac tissue engineering: cell seeding, cultivation parameters, and tissue construct characterization. Biotechnology and Bioengineering, 5;64(5), 580-9.

89. Masuda S, Shimizu T, Yamato M, Okano T. (2008) Cell sheet engineering for heart tissue repair. Advanced Drug Delivery Reviews, 60(2), 277-285.

90. Hashi CK, Zhu Y, Yang G, Young WL, Hsiao BS, Wang K, Chu B, Li S. (2007) Antithrombogenic property of bone marrow mesenchymal stem cells in nanofibrous vascular grafts. Proceedings of the National Academy of Sciences of the United States of America, 104 (29) p1191511920. https://doi.org/10.1073/pnas.0704581104.

91. Baheiraei N, Gharibi R, Yeganeh H, Miragoli M, Salvarani N, Di Pasquale E, Condorelli G. (2015) Electroactive polyurethane/siloxane derived from castor oil as a versatile cardiac patch, part I: Synthesis, characterization, and myoblast proliferation and differentiation. Journal of Biomedical Materials Research Part A., 104(3):775-787.

92. Baheiraei N, Gharibi R, Yeganeh H, Miragoli M, Salvarani N, Di Pasquale E, Condorelli G. (2016) Electroactive polyurethane/siloxane derived from castor oil as a versatile cardiac patch, part II: HL-1 cytocompatibility and electrical characterizations. Journal of Biomedical Materials Research Part A. 104(6):1398-1407.

93. Su W, Ho C, Shih T, Wang C, Yeh C. (2016) Exceptional biocompatibility of 3D fibrous scaffold for cardiac tissue engineering fabricated from biodegradable polyurethane blended with cellulose. International Journal of Polymeric Materials and Polymeric Biomaterials, 65(14):703-711.

94. Hernández-Córdova R, Mathew D, Balint R, Carrillo-Escalante H, Cervantes-Uc J, Hidalgo-Bastida L, Hernández-Sánchez F. (2016) Indirect three-dimensional printing: A method for fabricating polyurethane-urea based cardiac scaffolds. Journal of Biomedical Materials Research Part A., 104(8):1912-1921.

95. Tomecka E, Wojasinski M, Jastrzebska E, Chudy M, Ciach T, Brzozka Z. (2017) Poly( 1 -lactic acid) and polyurethane nanofibers fabricated by solution blow spinning as potential substrates for cardiac cell culture. Materials Science and Engineering: C., 75, 305-316

96. Sharifpanah F, Reinhardt M, Schönleben J, Meyer C, Richter M, Schnabelrauch M, Rode C, Wartenberg A, Bekhite M, Sauer H, Wartenberg M. (2017) Embryonic stem cells for tissue 
biocompatibility, angiogenesis, and inflammation testing. Cells Tissues Organs, 204: 1-12.

https://doi.org/10.1159/000471794

839

97. Centola M, Rainer A, Spadaccio C, De Porcellinis S, Genovese JA, Trombetta M. (2010) Combining electrospinning and fused deposition modelling for the fabrication of a hybrid vascular graft. Biofabrication. 2(1):014102.; doi: 0.1088/1758-5082/2/1/014102.

98. Mukherjee S, Reddy Venugopal J, Ravichandran R, Ramakrishna S, Raghunath M. (2011) Evaluation of the Biocompatibility of PLACL/Collagen Nanostructured Matrices with Cardiomyocytes as a Model for the Regeneration of Infarcted Myocardium. Advanced Functional Materials., 21(12):2291-2300.

99. Kai D, Prabhakaran M, Jin G, Ramakrishna S. (2011) Polypyrrole-contained electrospun conductive nanofibrous membranes for cardiac tissue engineering. Journal of Biomedical Materials Research Part A., 99A(3):376-385.

100. Sugiura T, Hibino N, Breuer C, Shinoka T. (2016) Tissue-engineered cardiac patch seeded with human induced pluripotent stem cell derived cardiomyocytes promoted the regeneration of host cardiomyocytes in a rat model. Journal of Cardiothoracic Surgery., 11(1). doi: 10.1186/s13019016-0559-z

101. Castilho M, Feyen D, Flandes-Iparraguirre M, Hochleitner G, Groll J, Doevendans P, Vermonden T, Ito K, Sluijter JPG, Malda J. (2017) Melt Electrospinning Writing of Poly-Hydroxymethylglycolideco- $\varepsilon$-Caprolactone-Based Scaffolds for Cardiac Tissue Engineering. Advanced Healthcare Materials., 6(18):1700311

102. Pok S, Myers JD, Madihally SV, Jacot JG. (2013) A multi-layered scaffold of a chitosan and gelatin hydrogel supported by a PCL core for cardiac tissue engineering. Acta Biomater., 9: 5630-5642.

103. Hitscherich P, Wu S, Gordan R, Xie L-H, Arinzeh T, Lee EJ. (2016) The effect of PVDF-TrFE scaffolds on stem cell derived cardiovascular cells. Biotechnol Bioeng., 113:1577-85. doi:10.1002/bit.25918

104. Nelson D, Ma Z, Fujimoto K, Hashizume R, Wagner W. (2011) Intra-myocardial biomaterial injection therapy in the treatment of heart failure: Materials, outcomes and challenges. Acta Biomaterialia. 7(1):1-15.

105. Herpel E, Pritsch M, Koch A, Dengler T, Schirmacher P, Schnabel P. (2006) Interstitial fibrosis in the heart: differences in extracellular matrix proteins and matrix metalloproteinases in end-stage dilated, ischaemic and valvular cardiomyopathy. Histopathology. 48 (6), 736-747.

106. Serpooshan V, Zhao M, Metzler S, Wei K, Shah P, Wang A, Mahmoudi M, Malkovskiy AV, Rajadas J, Butte MJ, Bernstein D, Ruiz-Lozano P. (2016) The effect of bioengineered acellular collagen patch on cardiac remodeling and ventricular function post myocardial infarction. Biomaterials. 34(36), 9048-9055. 
873

874

875

876

877

878

879

880

881

882

883

884

885

886

887

888

889

890

891

892

893

894

895

896

897

898

899

900

901

902

903

904

905

906

907

908

909

910

911

912

913

914
107. Dawson J, Schussler O, Al-Madhoun A, Menard C, Ruel M, Skerjanc I. (2011) Collagen scaffolds with or without the addition of RGD peptides support cardiomyogenesis after aggregation of mouse embryonic stem cells. In Vitro Cellular \& Developmental Biology - Animal, 47(9):653-664.

108. Yu H, Zhao H, Huang C, Du Y. (2017) Mechanically and Electrically Enhanced CNT-Collagen Hydrogels As Potential Scaffolds for Engineered Cardiac Constructs. ACS Biomaterials Science \& Engineering, 3(11), 3017-3021 doi: 10.1021/acsbiomaterials.6b0062

109. Sun H, Zhou J, Huang Z, Qu L, Lin N, Liang C, Dai R, Tang L, Tian F. (2017) Carbon nanotubeincorporated collagen hydrogels improve cell alignment and the performance of cardiac constructs. International Journal of Nanomedicine, 12:3109-3120.

110. Frederick J, Fitzpatrick J, McCormick R, Harris D, Kim A, Muenzer J, Marotta N, Smith MJ, Cohen JE, Hiesinger W, Atluri P, Woo YJ. (2010) Stromal Cell-Derived Factor-1 Activation of TissueEngineered Endothelial Progenitor Cell Matrix Enhances Ventricular Function After Myocardial Infarction by Inducing Neovasculogenesis. Circulation. 122(11 suppl: 1):S107-S117.

111. Hsieh SC, Chen HJ, Hsu SH, Yang YC, Tang CM, Chu MY, Lin PY, Fu RH, Kung ML, Chen YW, Yeh BW, Hung HS. (2016) Prominent Vascularization Capacity of Mesenchymal Stem Cells in Collagen-Gold Nanocomposites. ACS Applied Materials \& Interfaces. 8(42):28982-29000.

112. Nie SP, Wang X, Qiao SB, Zeng QT, Jiang JQ, Liu XQ, Zhu XM, Cao GX, Ma CS. (2010) Improved myocardial perfusion and cardiac function by controlled-release basic fibroblast growth factor using fibrin glue in a canine infarct model. Journal of Zhejiang University Science B., 11(12):895-904.

113. Menasché P, Vanneaux V, Fabreguettes JR, Bel A, Tosca L, Garcia S, Bellamy V, Farouz Y, Pouly J, Damour O, Périer MC, Desnos M, Hagège A, Agbulut O, Bruneval P, Tachdjian G, Trouvin JH, Larghero J. (2014) Towards a clinical use of human embryonic stem cell-derived cardiac progenitors: a translational experience. European Heart Journal, 36(12):743-750.

114. Gil-Cayuela C, Roselló-LLetí E, Ortega A, Tarazón E, Triviño J, Martínez-Dolz L, GonzálezJuanatey JR, Lago F, Portolés M, Rivera M. (2016) New Altered Non-Fibrillar Collagens in Human Dilated Cardiomyopathy: Role in the Remodeling Process. PLOS ONE., 11(12):e0168130.

115. Menasché P, Vanneaux V, Hagège A, Bel A, Cholley B, Cacciapuoti I, Parouchev A, Benhamouda N, Tachdjian G, Tosca L, Trouvin JH, Fabreguettes JR, Bellamy V, Guillemain R, SuberbielleBoissel C, Tartour E, Desnos M, Larghero J. (2015) Human embryonic stem cellderived cardiac progenitors for severe heart failure treatment: first clinical case report. European Heart Journal, 36(30):2011-7.

116. Terrovitis J, Lautamäki R, Bonios M, Fox J, Engles JM, Yu J, Leppo MK, Pomper MG, Wahl RL, Seidel J, Tsui BM, Bengel FM, Abraham MR, Marbán E. (2009). Noninvasive Quantification and Optimization of Acute Cell Retention by In Vivo Positron Emission Tomography After Intramyocardial Cardiac-Derived Stem Cell Delivery. Journal of the American College of Cardiology, 54(17):1619-1626.

117. Llucià-Valldeperas $\quad$ A, Soler-Botija C, Gálvez-Montón C, Roura S, Prat-Vidal C, Perea-Gil I, Sanchez B, Bragos R, Vunjak-Novakovic G, Bayes-Genis A. (2016) Electromechanical Conditioning of Adult Progenitor Cells Improves Recovery of Cardiac Function After Myocardial Infarction. STEM CELLS Translational Medicine. 6(3):970-981. 
915

916

917

918

919

920

921

922

923

924

925

926

927

928

929

930

931

932

933

934

935

936

937

938

939

940

941

942

943

944

945

946

947

948

949

950

951

952

953

954

955
118. Tao Z, Mohamed M, Hogan M, Gutierrez L, Birla R. (2014) Optimizing a spontaneously contracting heart tissue patch with rat neonatal cardiac cells on fibrin gel. Journal of Tissue Engineering and Regenerative Medicine. 11(1):153-163.

119. Ichihara Y, Tano N, Fields L, Murugesu N, Shintani Y, Ishida M, Sato N, Suzuki K. Abstract 14735: (2017) Epicardial Placement of Instantly Produced Fibrin Glue- Incorporating Mesenchymal Stromal Cells for the Treatment of Heart Failure [Internet]. Circulation. from: http://circ.ahajournals.org/content/134/Suppl_1/A14735

120. Moreira R, Neusser C, Kruse M, Mulderrig S, Wolf F, Spillner J, Schmitz-Rode T, Jockenhoevel S, Mela P. (2016) Tissue-Engineered Fibrin-Based Heart Valve with Bio-Inspired Textile Reinforcement. Advanced Healthcare Materials. 5(16):2113-2121.

121. Camci-Unal G, Annabi N, Dokmeci M, Liao R, Khademhosseini A. (2014) Hydrogels for cardiac tissue engineering. NPG Asia Materials., 6(5):e99.

122. Wang H, Shi J, Wang Y, Yin Y, Wang L, Liu J, Liu Z, Duan C, Zhu P, Wang C. (2014) Promotion of cardiac differentiation of brown adipose derived stem cells by chitosan hydrogel for repair after myocardial infarction. Biomaterials. 35(13):3986-3998.

123. Chopra S, Mahdi S, Kaur J, Iqbal Z, Talegaonkar S, Ahmad F. (2006) Advances and potential applications of chitosan derivatives as mucoadhesive biomaterials in modern drug delivery. Journal of Pharmacy and Pharmacology. 58(8):1021-1032

124. Wang L, Shansky J, Borselli C, Mooney D, Vandenburgh H. (2012) Design and Fabrication of a Biodegradable, Covalently Crosslinked Shape-Memory Alginate Scaffold for Cell and Growth Factor Delivery. Tissue Engineering Part A, 18(19-20):2000-2007.

125. Landa N, Miller L, Feinberg M, Holbova R, Shachar M, Freeman I, Ci. (2008) Effect of Injectable Alginate Implant on Cardiac Remodeling and Function After Recent and Old Infarcts in Rat. Circulation. 117(11):1388-1396.

126. Leor J, Tuvia S, Guetta V, Manczur F, Castel D, Willenz U, Petneházy O, Landa N, Feinberg MS, Konen E, Goitein O, Tsur-Gang O, Shaul M, Klapper L, Cohen S. (2009) Intracoronary Injection of In Situ Forming Alginate Hydrogel Reverses Left Ventricular Remodeling After Myocardial Infarction in Swine. Journal of the American College of Cardiology. 54(11):10141023.

127. Sabbah H, Wang M, Gupta R, Rastogi S, Ilsar I, Sabbah M, Kohli S, Helgerson S, Lee RJ. (2013) Augmentation of Left Ventricular Wall Thickness With Alginate Hydrogel Implants Improves Left Ventricular Function and Prevents Progressive Remodeling in Dogs With Chronic Heart Failure. JACC: Heart Failure. 1(3):252-258.

128. Bonafè F, Govoni M, Giordano E, Caldarera C, Guarnieri C, Muscari C. (2014) Hyaluronan and cardiac regeneration. Journal of Biomedical Science. 21: 100. doi: 10.1186/s12929-014-0100-4

129. Yoon SJ, Fang YH, Lim CH, Kim BS, Son HS, Park Y, Sun K. (2009) Regeneration of ischemic heart using hyaluronic acid-based injectable hydrogel. Journal of Biomedical Materials Research Part B: Applied Biomaterials. 91B (1):163-171. 
956

957

958

959

960

961

962

963

964

965

966

967

968

969

970

971

972

973

974

975

976

977

978

979

980

981

982

983

984

985

986

987

988

989

990

991

992

993

994

130. Yang MC, Chi NH, Chou NK, Huang YY, Chung TW, Chang YL, Liu HC, Shieh MJ, Wang SS. (2010) The influence of rat mesenchymal stem cell CD44 surface markers on cell growth, fibronectin expression, and cardiomyogenic differentiation on silk fibroin - Hyaluronic acid cardiac patches. Biomaterials. 31(5):854-862.

131.Göv E, Kenar H, Halbutoğullari Z, Arğa K, Karaöz E. (2016) Cardiomyogenic differentiation potential of human lipoaspirate-derivedstem cells on hyaluronic acid/gelatin plasma gels. Turkish Journal of Biology. 40:369-379.

132.Li RK, Jia ZQ, Weisel RD, Mickle DA, Choi A, Yau TM. (1999) Survival and function of bioengineered cardiac grafts. Circulation 100(19), 1163-1169.

133. McCain M, Agarwal A, Nesmith H, Nesmith A, Parker K. (2014) Micromolded gelatin hydrogels for extended culture of engineered cardiac tissues. Biomaterials. 35(21):5462-5471.

134. Yacoub M, Terrovitis J. (2013) CADUCEUS, SCIPIO, ALCADIA: Cell therapy trials using cardiac-derived cells for patients with post myocardial infarction LV dysfunction, still evolving. Global Cardiology Science and Practice. (1):3: 6-8

135. Takehara N, Tsutsumi Y, Tateishi K, Ogata T, Tanaka H, Ueyama T, Takahashi T, Takamatsu T, Fukushima M, Komeda M, Yamagishi M, Yaku H, Tabata Y, Matsubara H, Oh H. (2008) Controlled Delivery of Basic Fibroblast Growth Factor Promotes Human Cardiosphere-Derived Cell Engraftment to Enhance Cardiac Repair for Chronic Myocardial Infarction. Journal of the American College of Cardiology. 52(23):1858-1865.

136. Navaei A, Saini H, Christenson W, Sullivan R, Ros R, Nikkhah M. (2016) Gold nanorod-incorporated gelatin-based conductive hydrogels for engineering cardiac tissue constructs. ActaBiomaterialia. 41:133-146.

137. Kudová J, Procházková J, Vašiček O, Perečko T, Sedláčková M, Pešl M, Pacherník J, Kubala L. (2016) HIF-1alpha Deficiency Attenuates the Cardiomyogenesis of Mouse Embryonic Stem Cells. PLOS ONE. 11(6):e0158358.

138. Cristallini C, Cibrario Rocchietti E, Gagliardi M, Mortati L, Saviozzi S, Bellotti E, Turinetto V, Sassi MP, Barbani N, Giachino C. (2016). Micro- and Macrostructured PLGA/Gelatin Scaffolds Promote Early Cardiogenic Commitment of Human Mesenchymal Stem Cells In Vitro. Stem Cells International. 2016:1-16.

139. Okada M, Yamashita C, Okada M, Okada K. (1995). Role of Endothelin-1 in Beagles With Dehydromonocrotaline-Induced Pulmonary Hypertension. Circulation. 92(1):114-119.

140. Sakai T, Li RK, Weisel RD, Mickle DA, Kim ET, Jia ZQ, Yau TM. (2001). The fate of a tissueengineered cardiac graft in the right ventricular outflow tract of the rat. Journal of Thoracic and Cardiovascular Surgery 121(5), 932-942.

141.Zimmermann, W., Melnychenko, I., Eschenhagen, T. (2004). Engineered heart tissue for regeneration of diseased hearts. Biomaterials 25(9), 1639-1647.

142. Duan Y, Liu Z, O'Neill J, Wan LQ, Freytes DO, Vunjak-Novakovic G. (2011). Hybrid gel composed of native heart matrix and collagen induces cardiac differentiation of human embryonic stem 
995 cells without supplemental growth factors. Journal of Cardiovascular Translational Research 4(5), 605996615.

997 143.Lewis, T. (2016). The Scientist. Retrieved from the-scientist.com: http://mobile.thescientist.com/article/46588/will-organs-in-a-dish-ever-replace-animal-models.

999

1000

1001

1002

1003

1004

1005

1006

1007

1008

1009

1010

1011

1012

1013

1014

1015

1016

1017

1018

1019

1020

1021

1022

1023

1024

1025

1026

1027

1028

1029

1030

1031

1032

1033
144.Lu TY, Lin B, Kim J, Sullivan M, Tobita K, Salama G, Yang L. (2013). Repopulation of decellularized mouse heart with human induced pluripotent stem cell-derived cardiovascular progenitor cells. Nature Communications. 4:2307. doi: 10.1038/ncomms3307

145. Iop L, Renier V, Naso F, Piccoli M, Bonetti A, Gandaglia A, Pozzobon M, Paolin A, Ortolani F, Marchini M, Spina M, De Coppi P, Sartore S, Gerosa G. (2009). The influence of heart valve leaflet matrix characteristics on the interaction between human mesenchymal stem cells and decellularized scaffolds. Biomaterials 30(25), 4104-4116.

146. Yamato, M., \& Okano, T. (2004). Cell sheet engineering. Materials Today. Volume 7, Issue 5, Pages 42-47. https://doi.org/10.1016/S1369-7021(04)00234-2

147. Boroviak T., Loos R., Bertone P., Smit A., Nichols J. (2014). The ability of inner cell mass cells to self-renew as embryonic stem cells is acquired upon epiblast specification. Nature Cell Biology 16, 513-525.

148. Lundy SD, Zhu WZ, Regnier M, Laflamme MA. (2013). Structural and Functional Maturation of Cardiomyocytes Derived from Human Pluripotent Stem Cells. Stem Cells and Development. Jul 15;22(14):1991-2002. doi: 10.1089/scd.2012.0490.

149. Boheler KR, Czyz J, Tweedie D, Yang HT, Anisimov SV, Wobus AM. (2002). Differentiation of Pluripotent Embryonic Stem Cells Into Cardiomyocytes. Circulation Research. Aug 9;91(3):189201.

150. Takahashi K, Tanabe K, Ohnuki M, Narita M, Ichisaka T, Tomoda K, Yamanaka S. (2007). Induction of pluripotent stem cells from adult human fibroblasts by defined factors. Cell. Nov 30;131(5):861-72.

151. Yu J, Vodyanik MA, Smuga-Otto K, Antosiewicz-Bourget J, Frane JL, Tian S, Nie J, Jonsdottir GA, Ruotti V, Stewart R, Slukvin II, Thomson JA. (2007). Induced pluripotent stem cell lines derived from human somatic cells. Science. Dec 21;318(5858):1917-20

152. Bosman A, Edel MJ, Blue G, Dilley RJ, Harvey RP, Winlaw DS. (2015). Bioengineering and Stem Cell Technology in the Treatment of Congenital Heart Disease. Journal of Clinical Medicine. Apr 22;4(4):768-81. doi: 10.3390/jcm4040768.

153. Caputo M, Saif J, Rajakaruna C, Brooks M, Angelini GD, Emanueli C. (2015). MicroRNAs in vascular tissue engineering and post-ischemic neovascularization. Advanced Drug Delivery Reviews. Jul 1;88:78-91. doi: 10.1016/j.addr.2015.05.003.

154. Ieda M, Fu JD, Delgado-Olguin P, Vedantham V, Hayashi Y, Bruneau BG, Srivastava D. (2010). Direct Reprogramming of Fibroblasts into Functional Cardiomyocytes by Defined Factors. Cell. Aug 6;142(3):375-86. doi: 10.1016/j.cell.2010.07.002.

155. Lüningschrör P, Hauser S, Kaltschmidt B, Kaltschmidt C. (2013). MicroRNAs in pluripotency, reprogramming, and cell fate induction. BiochimicaetBiophysicaActa (BBA) - Molecular Cell Research. Aug;1833(8):1894-903. doi: 10.1016/j.bbamcr.2013.03.025. 
1034

1035

1036

1037

1038

1039

1040

1041

1042

1043

1044

1045

1046

1047

1048

1049

1050

1051

1052

1053

1054

1055

1056

1057

1058

1059

1060

1061

1062

1063

1064

1065

1066

1067

1068

1069

1070

1071

1072

1073

1074

156. Webera, B., Zeisbergera, S., Hoerstrup, S. ( 2011). Prenatally harvested cells for cardiovascular tissue engineering: Fabrication of autologous implants prior to birth. Placenta. Oct;32 Suppl 4:S316-9. doi: 10.1016/j.placenta.2011.04.001.

157. Murohara T, Ikeda H, Duan J, Shintani S, Sasaki Ki, Eguchi H, Onitsuka I, Matsui K, Imaizumi T. (2000). Transplanted cord blood-derived endothelial precursor cells augment postnatal neovascularization. The Journal of Clinical Investigation. Jun;105(11):1527-36.

158. De Coppi P, Bartsch G Jr, Siddiqui MM, Xu T, Santos CC, Perin L, Mostoslavsky G, Serre AC, Snyder EY, Yoo JJ, Furth ME, Soker S, Atala A. (2007). Isolation of amniotic stem cell lines with potential for therapy. Nature Biotechnology. Jan;25(1):100-6.

159. Schmidt D, Mol A, Breymann C, Achermann J, Odermatt B, Gössi M, Neuenschwander S, Prêtre R, Genoni M, Zund G, Hoerstrup SP. (2006). Living autologous heart valves engineered from human prenatally harvested progenitors. Circulation. Jul 4;114(1 Suppl):I125-31.

160. Schmidt D, Breymann C, Weber A, Guenter CI, Neuenschwander S, Zund G, Turina M, Hoerstrup SP. (2004). Umbilical Cord Blood Derived Endothelial Progenitor Cells for Tissue Engineering of Vascular Grafts. The Annal of Thoracic Surgery. Dec;78(6):2094-8

161. Schmidt D, Achermann J, Odermatt B, Breymann C, Mol A, Genoni M, Zund G, Hoerstrup SP. (2007). Prenatally fabricated autologous human living heart valves based on amniotic fluid derived progenitor cells as single cell source. Circulation. 11;116(11 Suppl):I64-70.

162. Yao, C. (2016). Combination of Endothelial Progenitor Cells, Extracellular Matrix and Aligned Eletrospun Polyhydroxyalkanoate Scaffold for Vascular Tissue Engineering. Cytotherapy. 18(6) Supplement, S75. https://doi.org/10.1016/j.jcyt.2016.03.149

163. Petsche Connell J, Camci-Unal G, Khademhosseini A, Jacot JG. (2013). Amniotic Fluid-Derived Stem Cells for Cardiovascular Tissue Engineering Applications. Tissue Engineering. Aug;19(4):368-79. doi: 10.1089/ten.TEB.2012.0561

164. Asahara T, Murohara T, Sullivan A, Silver M, van der Zee R, Li T, Witzenbichler B, Schatteman G, Isner JM.(1997). Isolation of putative progenitor endothelial cells for angiogenesis. Science. Feb 14;275(5302):964-7.

165.Zisch, A. (2004). Tissue engineering of angiogenesis with autologous endothelial progenitor cells. Current Opinion in Biotechnology. 15(5):424-9.

166. Olausson M, Kuna VK, Travnikova G, Bäckdahl H, Patil PB, Saalman R, Borg H, Jeppsson A, SumitranHolgersson S. (2014). In Vivo Application of Tissue-Engineered Veins Using Autologous Peripheral Whole Blood: A Proof of Concept Study. Ebiomedicine. Sep22;1(1):72-9. doi: 10.1016/j.ebiom.2014.09.001.

167.Zhou M, Liu Z, Liu C, Jiang X, Wei Z, Qiao W, Ran F, Wang W, Qiao T, Liu C. (2012). Tissue engineering of small-diameter vascular grafts by endothelial progenitor cells seeding heparincoated decellularized scaffolds. Journal of Biomedical Materials Research. 100(1):111-20. doi: 10.1002/jbm.b.31928.

168. Sales VL, Mettler BA, Engelmayr GC Jr, Aikawa E, Bischoff J, Martin DP, Exarhopoulos A, Moses MA, Schoen FJ, Sacks MS, Mayer JE Jr. (2011). Endothelial Progenitor Cells as a Sole Source for Ex Vivo Seeding of Tissue-Engineered Heart Valves. Tissue Engineering. 16(1):257-67. doi: 10.1089/ten.TEA.2009.0424. 
1075

1076

1077

1078

1079

1080

1081

1082

1083

1084

1085

1086

1087

1088

1089

1090

1091

1092

1093

1094

1095

1096

1097

1098

1099

1100

1101

1102

1103

1104

1105

1106

1107

1108

1109
169. Mirensky TL, Hibino N, Sawh-Martinez RF, Yi T, Villalona G, Shinoka T, and Breuer CK. (2010). Tissue-engineered vascular grafts: does cell seeding matter? Journal of Pediatric Surgery. 45(6): 1299-1305. doi: 10.1016/j.jpedsurg.2010.02.102.

170. Fernandes S, Chong JJH, Paige SL, Iwata M, Torok-Storb B, Keller G, Reinecke H, Murry CE. (2015). Comparison of Human Embryonic Stem Cell-Derived Cardiomyocytes, Cardiovascular Progenitors, and Bone Marrow Mononuclear Cells for Cardiac Repair. Stem Cell Reports 5(5): 753-762. doi: 10.1016/j.stemcr.2015.09.011.

171.Vincentelli A, Wautot F, Juthier F, Fouquet O, Corseaux D, Marechaux S, Le Tourneau T, Fabre O, Susen S, Van Belle E, Mouquet F, Decoene C, Prat A, Jude B. (2007). In vivo autologous recellularization of a tissue-engineered. Surgery. Aug;134(2):424-32.

172. Vicinanza C, Aquila I, Scalise M, Cristiano F, Marino F, Cianflone E, Mancuso T, Marotta P, Sacco W, Lewis FC, Couch L, Shone V, Gritti G, Torella A, Smith AJ, Terracciano CMN, Britti D, Veltri P, Indolfi C, Nadal-Ginard B, Ellison-Hughes GM, and Torella D (2017). Adult cardiac stem cells are multipotent and robustly myogenic: c-kit expression is necessary but not sufficient for their identification. Cell Death and Differentiation. 24, 2101-2116.

173. Bosman A, Edel MJ, Blue G, Dilley RJ, Harvey RP, Winlaw DS. (2011). Bioengineering and Stem Cell Technology in the Treatment of Congenital Heart Disease. Circulation. Apr 22;4(4):768-81. doi: $10.3390 / \mathrm{jcm} 4040768$.

174. Alessandri, G., Emanueli, C., \& Madedu, P. (2004). Genetically Engineered Stem Cell Therapy for Tissue Regeneration. Annals of the New York Academy of Science. May; 1015:271-84. DOI:10.1196/annals.1302.023.

175. Metcalfe AD and Ferguson MWJ. (2007). Tissue engineering of replacement skin: the crossroads of biomaterials, wound healing, embryonic development, stem cells, and regeneration. The Royal Society Interface. Jun 22; 4(14): 413-437. doi: 10.1098/rsif.2006.0179

176. Makris EA, Gomoll AH, Malizos KN, Hu JC, Athanasiou KA (2015). Repair and tissue engineering techniques for articular cartilage. Nature Reviews Reumatology. 11(1): 21-34. doi: 10.1038/nrrheum.2014.157

177. Chlupác, J., Filová, E., Bacáková, E. (2009) Blood vessel replacement: 50 years of development and tissue engineering paradigms in vascular surgery. Physiological Research ;58 Suppl 2:S119-39.

178. Karamichos, D. (2015) Ocular Tissue Engineering: Current and Future Directions. Journal of Functioning Biomaterials. Feb 17;6(1):77-80. doi: 10.3390/jfb6010077.

179. Kane NM, Thrasher AJ, Angelini GD, Emanueli C. (2014). Concise Review: MicroRNAs as Modulators of Stem Cells and Angiogenesis. Stem Cell. May;32(5):1059-66. doi: $10.1002 /$ stem. 1629 . 


\section{Table $\mathbf{1}$ (on next page)}

Frequencies of CHDs in some regions 


\begin{tabular}{|c|l|}
\hline \multicolumn{2}{|c|}{ Frequencies of CHD in some regions } \\
\hline United State & Affects 1\% of live births [33] \\
\hline South America & $\begin{array}{l}\text { Colombia: 1.2 per 1000 live births } \\
\text { Brazil (Minas Gerais): 9.58 in } 1000 \text { live births } \\
\text { Brazil (Londrina): 5.49 in } 1000 \text { live births [30] }\end{array}$ \\
\hline Mexico & $\begin{array}{l}\text { Affects 6-8 per 1,000 newborns. Drawing to the conclusion that there about } \\
12,000 \text { or 16,000 babies living with CHD [36] }\end{array}$ \\
\hline Asia & Affects 9.3 per 1,000 live births [34] \\
\hline Europe & Affects 8.2 per 100 live births [40] \\
\hline United kingdom & Affects about 9 in every 1,000 babies [35] \\
\hline Russia & $\begin{array}{l}\text { Affects 2.7-3.8 per 1,000 newborns estimating as 86 newborns per year being } \\
\text { affected with CHD [38] }\end{array}$ \\
\hline Australia & $\begin{array}{l}\text { Affects 8-10 cases per 1,000 live births. Resulting in 2,400-3,000 newborns } \\
\text { with CHD each year. About 65,000 adults are living with CHD [37] }\end{array}$ \\
\hline Africa & $\begin{array}{l}\text { Mozambique: 2.3 in 1000 live births } \\
\text { Northern Nigeria: 9.3\% (122 of 1312 patients) [41] }\end{array}$ \\
\hline Canada & Affects 1 in 80-100 live births [42] \\
\hline
\end{tabular}

3 
Table 2 (on next page)

Types, presentations and management of CHDs 


\begin{tabular}{|c|c|c|}
\hline Types of CHD & Presentations of CHD & $\begin{array}{c}\text { Medical \& Surgical } \\
\text { Therapeutic Approach to } \\
\text { CHD }\end{array}$ \\
\hline Atrial Septal Defects & $\begin{array}{l}\text { This defect manifests as a hole } \\
\text { in the wall (septum) that } \\
\text { separates the chambers above } \\
\text { (atria) from those below } \\
\text { (ventricles). } \\
\text { The volume of blood that } \\
\text { flows through the lungs is } \\
\text { increased over time due to the } \\
\text { hole caused by the atrial defect } \\
\text { resulting in damage to the } \\
\text { blood vessels in the lungs. } \\
>\text { Frequent respiratory or lung } \\
\text { infections } \\
>\text { Difficulty breathing } \\
>\text { Tiring when feeding (infants) } \\
>\text { Shortness of breath when } \\
\text { being active or exercising } \\
>\text { Skipped heartbeats or a sense } \\
\text { of feeling the heartbeat } \\
>\text { A heart murmur, or a } \\
\text { whooshing sound that can be } \\
\text { heard with a stethoscope } \\
>\text { Stroke } \\
>\text { Swelling of legs, feet, or } \\
\text { stomach area [31]. }\end{array}$ & $\begin{array}{l}\text { Medical monitoring: } \\
\text { the patient is monitored } \\
\text { to see if the atrial septal } \\
\text { defect would close on its } \\
\text { own. } \\
>\text { Medications: beta } \\
\text { blockers (to maintain a } \\
\text { regular heartbeat) or } \\
\text { anticoagulants (to help } \\
\text { reduce blood clots). } \\
>\text { Surgery: can be done } \\
\text { through Cardiac } \\
\text { catheterization or Open- } \\
\text { heart surgery. } \\
>\text { Follow-up care [31, 32] }\end{array}$ \\
\hline Hypoplas & $\begin{array}{l}\text { This defect affects the normal } \\
\text { blood flow through the heart. } \\
\text { The left side of the heart does } \\
\text { not form correctly and as such } \\
\text { it is considered a critical } \\
\text { congenital heart defect. } \\
\text { The following structures on the } \\
\text { left side of the heart is affected: } \\
\text { a. The left ventricle is } \\
\text { underdeveloped. } \\
\text { b. The mitral valves are not } \\
\text { formed. } \\
\text { c. The aortic valve is not } \\
\text { formed. } \\
\text { d. The ascending aorta is }\end{array}$ & $\begin{array}{l}\text { Medication: inpatient } \\
\text { medications include } \\
\text { prostaglandin E1, } \\
\text { Dopamine and } \\
\text { Potassium Chloride and } \\
\text { outpatient medications } \\
\text { are Furosemide, Digoxin } \\
\text { and Captopril [39]. } \\
>\text { Nutrition: feeding tube } \\
\text { or special high-calorie } \\
\text { formula. } \\
>\text { Surgery: } \\
\text { a. Norwood Procedure: } \\
\text { performed on the infant } \\
\text { within 2 weeks of a }\end{array}$ \\
\hline
\end{tabular}




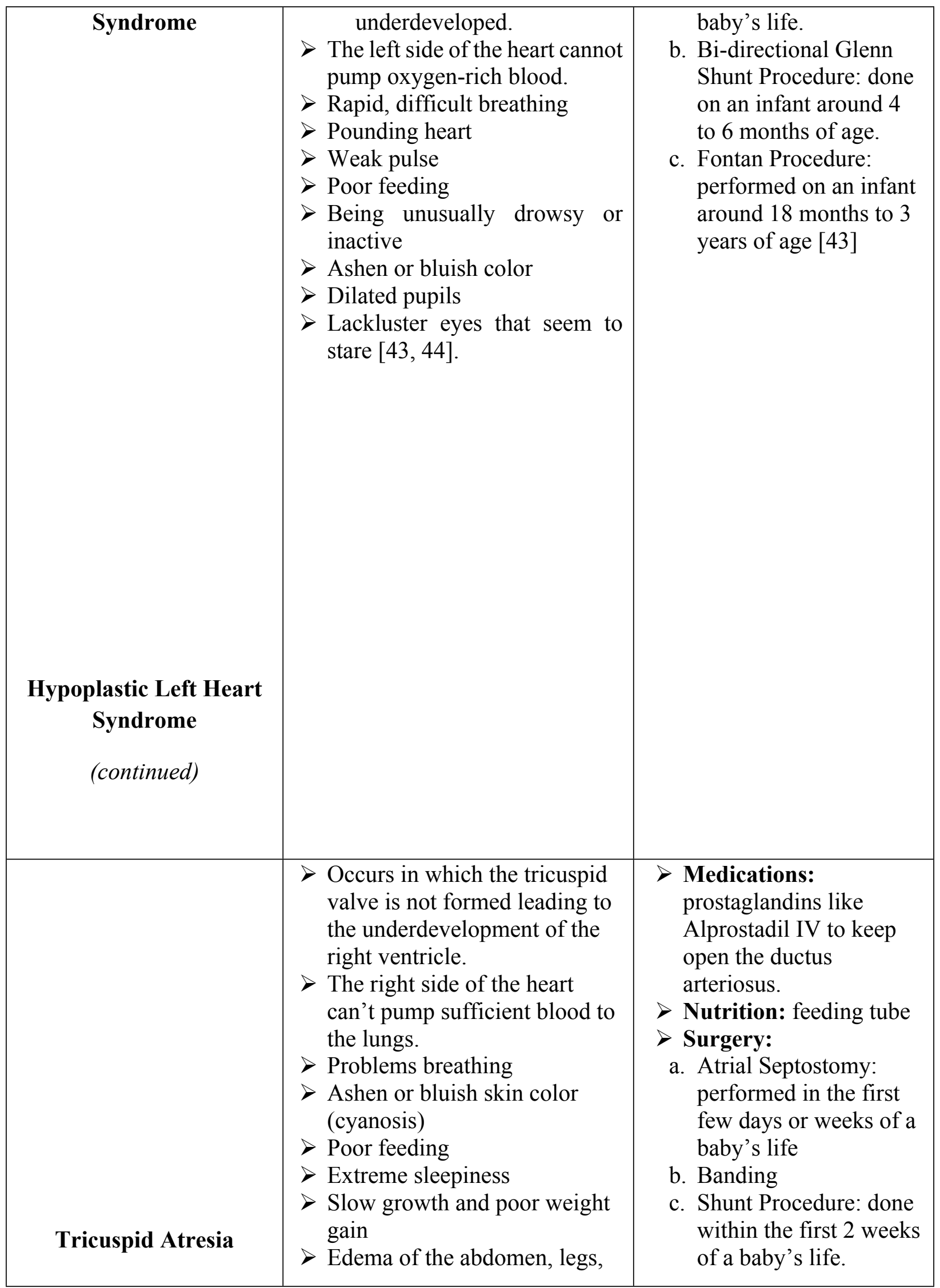




\begin{tabular}{|c|c|c|}
\hline & ankles and feet $[45,46]$. & $\begin{array}{l}\text { d. Bi-directional Glenn } \\
\text { Procedure: performed } \\
\text { around } 4 \text { to } 6 \text { months } \\
\text { of the baby's life. } \\
\text { e. Fontan Procedure: } \\
\text { done around } 2 \text { years of } \\
\text { age [45]. }\end{array}$ \\
\hline Tetraogy of Fallot & $\begin{aligned} & \text { Has a combination of four } \\
& \text { heart defects. This defect is a } \\
& \text { combination of pulmonary } \\
& \text { stenosis, ventricular septal } \\
& \text { defect, overriding aorta and } \\
& \text { right ventricular hypertrophy. } \\
> & \text { Cyanosis } \\
> & \text { Shortness of breath } \\
> & \text { Rapid breathing especially } \\
& \text { during feeding or exercise } \\
> & \text { Fainting } \\
> & \text { Clubbing of fingers and toes } \\
> & \text { Poor weight gain } \\
> & \text { Fatigue during play or } \\
& \text { exercise } \\
> & \text { Prolonged crying } \\
> & \text { Irritability } \\
> & \text { Heart murmur due to } \\
& \text { pulmonary stenosis [47, 48]. }\end{aligned}$ & $\begin{array}{l}\text { Medication: } \\
\text { Prostaglandin } \mathrm{E}_{1} \\
\text { infusion. } \\
>\text { Surgery: } \\
\text { a. Temporary surgery } \\
\text { (palliative surgery): } \\
\text { improve blood flow to } \\
\text { the lungs. } \\
\text { b. Intra-cardiac repair: } \\
\text { done during the first } \\
\text { year after birth [47]. }\end{array}$ \\
\hline \multicolumn{3}{|l|}{ Tetraogy of Fallot } \\
\hline & $\begin{array}{l}\text { Has only two (bicuspid) cusps } \\
\text { instead of three. } \\
\text { A bicuspid aortic valve may } \\
\text { result in the heart's aortic } \\
\text { valve to narrow (aortic valve } \\
\text { stenosis) which prevents the }\end{array}$ & $\begin{array}{l}\text { Surgery: } \\
\text { a. Aortic valve } \\
\text { replacement } \\
\text { b. Balloon valvuloplasty } \\
\text { c. Aortic valve repair } \\
\text { d. Aortic root and }\end{array}$ \\
\hline
\end{tabular}




\begin{tabular}{|c|c|c|}
\hline Bicuspid Aortic Valve & $\begin{aligned} & \text { valve from opening } \\
& \text { completely, which reduces or } \\
& \text { blocks blood flow from the } \\
& \text { heart to the body. } \\
> & \text { Trouble breathing } \\
> & \text { Chest pain or pressure } \\
> & \text { Fatigue } \\
> & \text { Heart racing } \\
> & \text { Light-headedness } \\
> & \text { Fainting [49]. }\end{aligned}$ & $\begin{array}{l}\text { ascending aorta } \\
\text { surgery }[50]\end{array}$ \\
\hline $\begin{array}{c}\text { Patent Ductus } \\
\text { Arteriosus }\end{array}$ & $\begin{aligned} &> \text { A persistent opening between } \\
& \text { the two major blood vessels } \\
& \text { leading from the heart. } \\
&>\text { Large patent arteriosus can } \\
& \text { cause poorly oxygenated } \\
& \text { blood to flow in the wrong } \\
& \text { direction. } \\
&>\text { Poor eating leads to poor } \\
& \text { growth. } \\
&>\text { Sweating with crying or eating } \\
&>\text { Persistent fast breathing or } \\
& \text { breathlessness } \\
&>\text { Easy tiring } \\
&>\text { Rapid heart taste }[51] .\end{aligned}$ & $\begin{aligned} & \text { Medications: NSAIDS } \\
& \text { (Advil, Infant's Motrin), } \\
& \text { or indomethacin } \\
& \text { (Indocin) [51] } \\
&>\text { Surgery: Video-assisted } \\
& \text { thoracic surgical } \\
& \text { (VATS) repair } \\
&>\text { Catheter procedure: } \\
& \text { Trans-catheter occlusion } \\
& \text { [52] } \\
&>\text { Watchful waiting }\end{aligned}$ \\
\hline Pulmonic Valve Stenosis & $\begin{array}{l}\text { This defect affects the } \\
\text { pulmonic valve in which a } \\
\text { deformity on or near the valve } \\
\text { causes it to be smaller and as } \\
\text { such slows the blood flow. } \\
\text { The narrowing is due to the } \\
\text { underdevelopment of the valve } \\
\text { during fetal growth. The } \\
\text { cusps maybe defective or too } \\
\text { thick or may not separate from } \\
\text { each other well. } \\
>\text { Heart murmur } \\
>\text { Fatigue } \\
>\text { Shortness of breath, especially } \\
\text { during exertion } \\
>\text { Chest pain } \\
>\text { Fainting [53] }\end{array}$ & $\begin{array}{l}\text { Surgery: } \\
\text { a. Balloon valvulplasty } \\
\text { b. Open-heart surgery } \\
{[53]}\end{array}$ \\
\hline
\end{tabular}




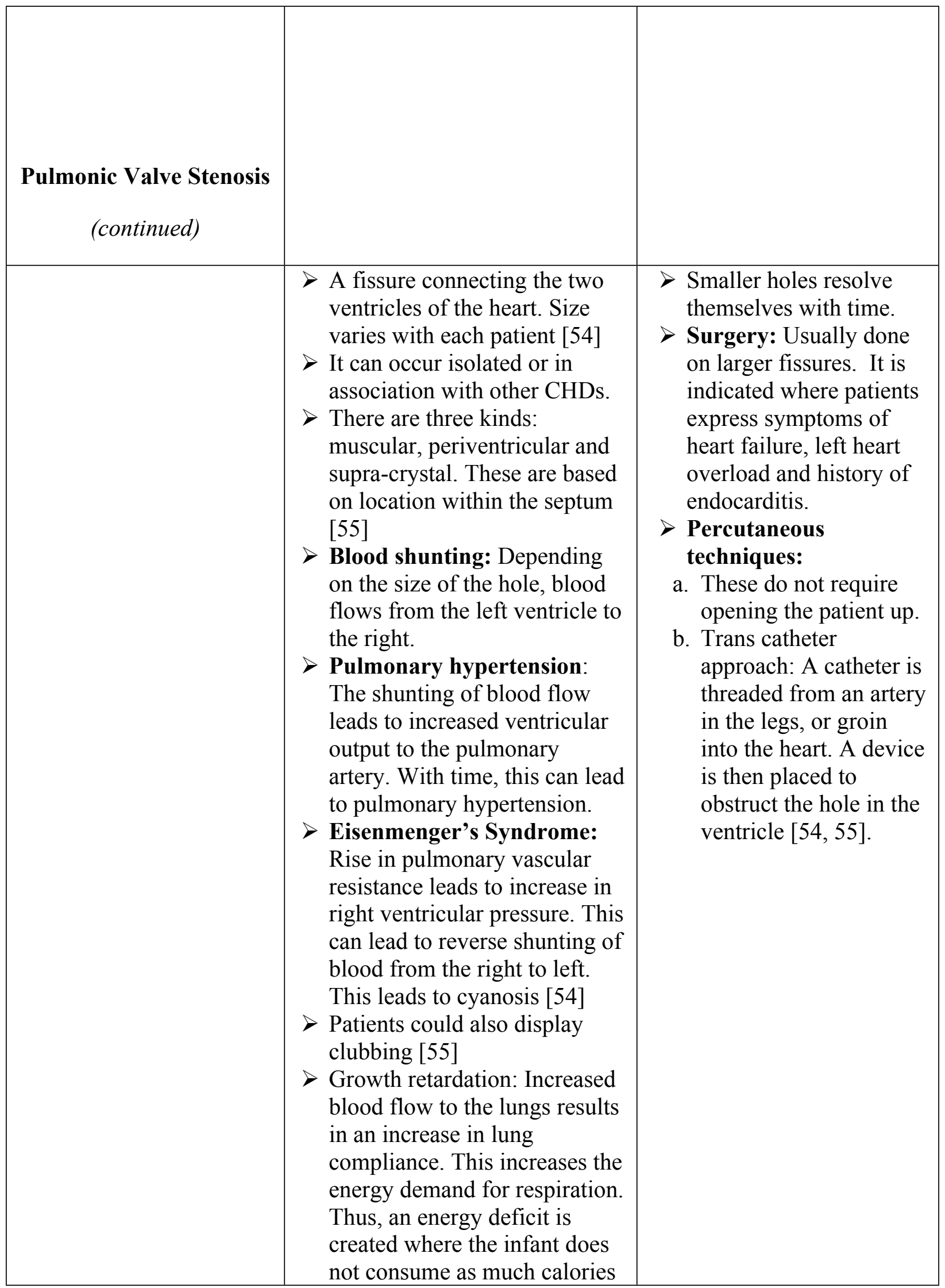




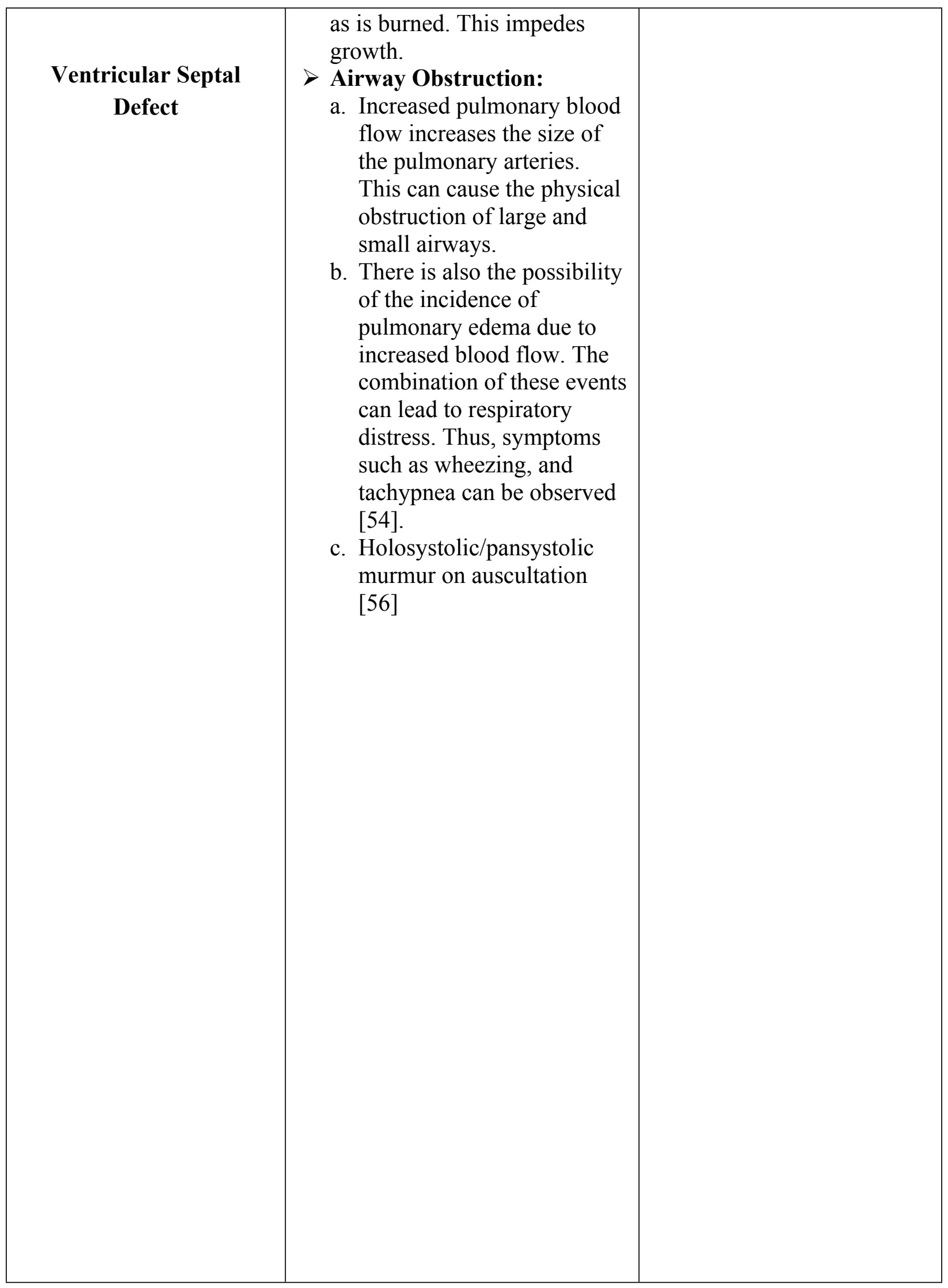




\begin{tabular}{|c|c|c|}
\hline \multicolumn{3}{|l|}{$\begin{array}{c}\text { Ventricular Septal } \\
\text { Defect } \\
\text { (continued) }\end{array}$} \\
\hline \multirow[t]{2}{*}{$\begin{array}{l}\text { Total Anomalous } \\
\text { Pulmonary Venous } \\
\text { Condition }\end{array}$} & $\begin{array}{l}\text { The pulmonary veins are } \\
\text { attached to the right atrium } \\
\text { instead of the left. } \\
\text { Usually associated with atrial } \\
\text { septal defect. } \\
\text { Cyanosis: Oxygenated blood } \\
\text { from the lungs is pumped into } \\
\text { the right atrium. It mixes with } \\
\text { deoxygenated blood and } \\
\text { passes through the atrial } \\
\text { septal defect into the left } \\
\text { atrium. This decreases } \\
\text { oxygen supply to the body } \\
\text { leading to cyanosis. } \\
\text { Pulmonary hypertension: } \\
\text { Some patients have } \\
\text { constricted pulmonary veins } \\
\text { that lead to pulmonary } \\
\text { hypertension. This leads to } \\
\text { pulmonary effusion. } \\
\text { Hypovolemia: Some patients } \\
\text { manifest with a narrow or } \\
\text { restrictive atrial septal defect. } \\
\text { This significantly reduces the } \\
\text { blood flow to the body } \\
\text { leading to hypovolemia [57]. }\end{array}$ & $\begin{array}{l}\text { Surgery: The } \\
\text { pulmonary veins are } \\
\text { surgically reattached to } \\
\text { the left atrium. } \\
\text { Cardiac } \\
\text { catheterization: For the } \\
\text { patients with a restricted } \\
\text { atrial septal defect, a } \\
\text { balloon pump is used to } \\
\text { widen the fissure until } \\
\text { corrective surgery can } \\
\text { be carried out [57] }\end{array}$ \\
\hline & $\begin{array}{l}\text { A condition whereby the aorta } \\
\text { and the pulmonary arteries are } \\
\text { transposed. The aorta arises } \\
\text { from the right ventricle and }\end{array}$ & $\begin{array}{l}\text { Medications: } \\
\text { Prostaglandin E1 is } \\
\text { administered to keep the } \\
\text { ductus arteriosus open. }\end{array}$ \\
\hline
\end{tabular}




\begin{tabular}{|c|c|c|}
\hline $\begin{array}{l}\text { Trans-Position of the } \\
\text { Great Arteries }\end{array}$ & $\begin{array}{l}\text { leads to the lungs. The } \\
\text { pulmonary artery arises from } \\
\text { the left ventricle and leads to } \\
\text { the body. } \\
\text { It is comorbid with ventricular } \\
\text { septal defect and patent ductus } \\
\text { arteriosus. } \\
\text { Cyanosis:Mixing of blood } \\
\text { leads to supply of poorly } \\
\text { oxygenated blood to the body } \\
\text { [58] }\end{array}$ & $\begin{array}{l}\text { Surgery: } \\
\text { a. Balloon atrial } \\
\text { septostomy: A } \\
\text { catheter is threaded } \\
\text { through the foramen } \\
\text { ovale. A balloon is } \\
\text { inflated to rip a } \\
\text { fissure in the atrium } \\
\text { [58] }\end{array}$ \\
\hline $\begin{array}{l}\text { Trans-Position of the } \\
\text { Great Arteries } \\
\text { (continued) }\end{array}$ & & \\
\hline \multirow[t]{2}{*}{ Truncus Arterious } & $\begin{array}{l}>\text { A condition where the truncus } \\
\text { arteriosus of a fetus does not } \\
\text { differentiate into an aorta and } \\
\text { pulmonary vein. Thus, the } \\
\text { patient only has one vessel } \\
\text { exiting the heart } \\
\text { Cyanosis: This leads to } \\
\text { mixing of oxygenated and } \\
\text { deoxygenated blood. Thus, } \\
\text { the oxygen supply to the body } \\
\text { is decreased } \\
\text { Congestive heart failure: the } \\
\text { excess of volume of blood } \\
\text { flow to the heart increases } \\
\text { pressure in the lungs. This } \\
\text { would eventually lead to } \\
\text { cardiac failure. } \\
\text { Usually comorbid with } \\
\text { ventricular septal defect [59] }\end{array}$ & $\begin{array}{l}\text { Surgery: The truncus } \\
\text { arteriosus must be } \\
\text { separated into two } \\
\text { vessels. This would } \\
\text { allow separate blood } \\
\text { flow channels to the } \\
\text { heart and body [59] }\end{array}$ \\
\hline & $\begin{array}{l}>\quad \begin{array}{l}\text { A congenital malformation of } \\
\text { the tricuspid valve }\end{array} \\
\text { The posterior and septal } \\
\text { leaflets are displaced } \\
\text { downwards. This leads to a } \\
\text { downward enlargement of the } \\
\text { right atrium. } \\
>\quad \text { The walls of the right atrium }\end{array}$ & $\begin{array}{l}\text { Surgery: } \\
\text { a. Only required where } \\
\text { patient manifests } \\
\text { severe symptoms. } \\
\text { b. Cone procedure: } \\
\text { Where the anterior } \\
\text { septal leaflet is } \\
\text { maneuvered and }\end{array}$ \\
\hline
\end{tabular}




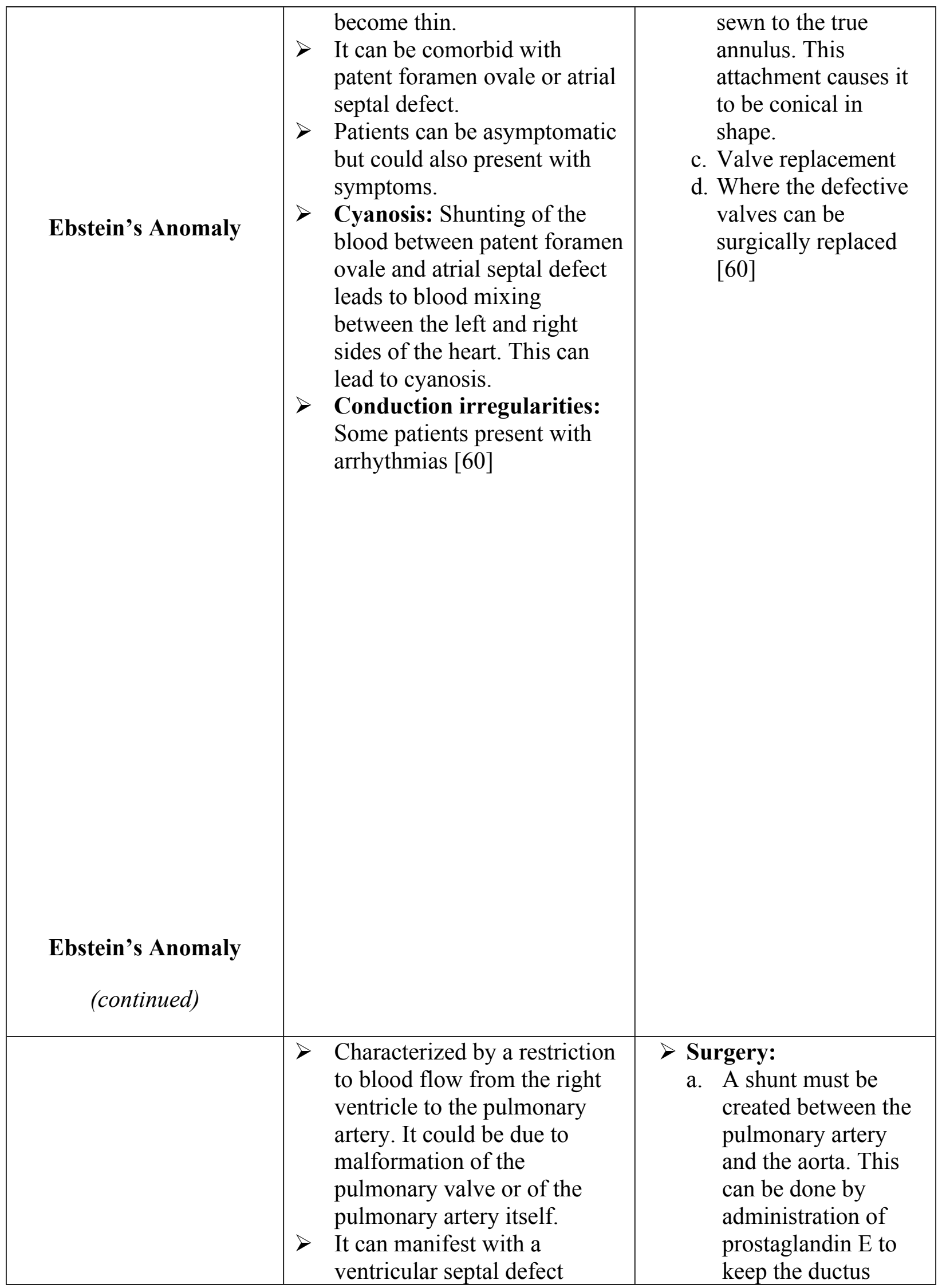




\begin{tabular}{|c|c|c|}
\hline Pulmonary Atresia & $\begin{array}{l}\text { where there are collateral } \\
\text { arteries supplying the lungs. } \\
\text { It could also manifest without } \\
\text { a ventricular septal defect. } \\
\text { Here the right ventricle is } \\
\text { usually hypoplastic. It would } \\
\text { usually be comorbid with a } \\
\text { patent ductus arteriosus [61]. }\end{array}$ & $\begin{array}{l}\text { arteriosus open. It } \\
\text { could also be doe } \\
\text { surgically. } \\
\text { b. Fontan's procedure: } \\
\text { Done for patients } \\
\text { with a hypoplastic } \\
\text { right ventricle. The } \\
\text { right atrium is } \\
\text { surgically connected } \\
\text { to the pulmonary } \\
\text { artery [61]. }\end{array}$ \\
\hline Aortic Stenosis & $\begin{array}{l}>\text { Defect of the aortic valve that } \\
\text { restricts its opening. } \\
>\text { It can lead to ventricular } \\
\text { hypertrophy which can } \\
\text { eventually lead to heart } \\
\text { failure. } \\
>\text { There is also a possibility of } \\
\text { development of atrial } \\
\text { fibrillation. } \\
>\text { Presence of systolic murmur } \\
\text { [62] }\end{array}$ & $\begin{array}{l}\text { Valve replacement : } \\
\text { There are two } \\
\text { approaches: } \\
\text { a. Surgically } \\
\text { b. Trans-catheter } \\
\text { approach [62]. }\end{array}$ \\
\hline $\begin{array}{c}\text { Coarctation of the } \\
\text { Aorta }\end{array}$ & $\begin{array}{l}>\text { It is the constriction of the } \\
\text { proximal end of the aorta } \\
\text { leading to restriction to blood } \\
\text { flow. } \\
\text { Patients can present with } \\
\text { acidosis, cardiac failure, as } \\
\text { well as shock after ductus } \\
\text { arteriosus closes [63] }\end{array}$ & $\begin{array}{l}\text { Surgery: } \\
\text { a. Coarcted potion can } \\
\text { be resected. And the } \\
\text { ends of the artery can } \\
\text { be re-anastomosed. } \\
\text { b. A patch can also be } \\
\text { used to surgically } \\
\text { dilate the artery. } \\
\text { Balloon Angioplasty: } \\
\text { A catheter is threaded in } \\
\text { to the aorta. A balloon } \\
\text { is inflated to enlarge the } \\
\text { aorta. }\end{array}$ \\
\hline
\end{tabular}

2 


\section{Table 3(on next page)}

Advantages and disadvantages of materials and biomaterials used in TE 


\begin{tabular}{|c|c|c|c|c|}
\hline & $\begin{array}{l}\text { Artificial } \\
\text { Prosthesis }\end{array}$ & $\begin{array}{l}\text { Biological } \\
\text { Prosthesis }\end{array}$ & $\begin{array}{l}\text { Biomaterial } \\
\text { Scaffolds }\end{array}$ & $\begin{array}{l}\text { Scaffoldless } \\
\text { Tissue }\end{array}$ \\
\hline Advantages & $\begin{array}{l}\text { - Available in } \\
\text { abundance } \\
\text { - Many different } \\
\text { sizes } \\
\text { - Long term } \\
\text { results available }\end{array}$ & $\begin{array}{l}\text { - Available in } \\
\text { abundance } \\
\text { - No requirement } \\
\text { for life-long } \\
\text { treatment with } \\
\text { anticoagulants }\end{array}$ & $\begin{array}{l}\bullet \text { Good } \\
\text { mechanical } \\
\text { properties } \\
\bullet \text { Ultrastructural } \\
\text { features } \\
\bullet \text { Cell adherence } \\
\bullet \text { Biocompatibility } \\
\bullet \text { Biodegradable }\end{array}$ & $\begin{array}{l}\text { - No need for } \\
\text { scaffold } \\
\text { - Spontaneous } \\
\text { and } \\
\text { synchronous } \\
\text { pulsation } \\
\text { - Could create } \\
\text { tubular } \\
\text { construct } \\
\text { - Can grow with }\end{array}$ \\
\hline Disadvantages & $\begin{array}{l}\text { - Impact \& } \\
\text { friction wear } \\
\text { - Inflammation } \\
\text { - Calcification of } \\
\text { valve } \\
\text { - Less flexible } \\
\text { than natural } \\
\text { tissue } \\
\text { - Life-long } \\
\text { treatment with } \\
\text { anticoagulants }\end{array}$ & $\begin{array}{l}\text { - Risk of } \\
\text { cytotoxicity } \\
\text { - Inflammation } \\
\text { - Loss of } \\
\text { mechanical } \\
\text { properties } \\
\text { - Calcification in } \\
\text { infants and } \\
\text { children } \\
\text { - Immunological } \\
\text { reactions }\end{array}$ & $\begin{array}{l}\text { - Some present } \\
\text { toxicity } \\
\text { - Risk of } \\
\text { inflammation } \\
\text { - Not all tune } \\
\text { well with heart }\end{array}$ & $\begin{array}{l}\text { - Limited number } \\
\text { of cell sheets } \\
(\max 3) \\
\text { - Poor } \\
\text { vascularization } \\
\text { in more than } 3 \\
\text { cell-sheets }\end{array}$ \\
\hline
\end{tabular}




\section{Table 4 (on next page)}

Scaffolds and SCs used for TE in some study models 
1

\begin{tabular}{|c|c|c|c|c|}
\hline $\begin{array}{l}\text { Engineered } \\
\text { tissue }\end{array}$ & Scaffold & Type of SCs & Study models & Reference \\
\hline \multirow[t]{3}{*}{ Heart valve } & $\begin{array}{l}\text { Synthetic } \\
\text { biodegradable } \\
\text { non-woven } \\
\text { PGA mesh }\end{array}$ & $\begin{array}{l}\text { Human } \\
\text { Chorionic villi- } \\
\text { derived cells \& } \\
\text { hCB- EPCs }\end{array}$ & $\begin{array}{l}\text { Culture in } \\
\text { bioreactor }\end{array}$ & 164 \\
\hline & $\begin{array}{l}\text { Synthetic } \\
\text { biodegradable }\end{array}$ & hAFSCs & $\begin{array}{l}\text { Culture in } \\
\text { bioreactor }\end{array}$ & 166 \\
\hline & $\begin{array}{l}\text { porcine } \\
\text { decellularized } \\
\text { scaffold }\end{array}$ & $\begin{array}{l}\text { BM-MSCs } \\
\& \\
\text { BM-MSCs }\end{array}$ & Lambs & 176 \\
\hline \multirow[t]{3}{*}{ Vascular graft } & $\begin{array}{l}\text { Various } \\
\text { synthetic } \\
\text { biodegradable }\end{array}$ & $\begin{array}{l}\text { Human } \\
\text { Umbilical CB- } \\
\text { EPCs }\end{array}$ & $\begin{array}{l}\text { Static conditions } \\
\& \quad \text { biomimetic } \\
\text { flow system }\end{array}$ & 165 \\
\hline & $\begin{array}{l}\text { biodegradable } \\
\text { non-woven } \\
\text { PGA }\end{array}$ & BM-MNCs & Mice & 174 \\
\hline & $\begin{array}{l}\text { Biodegradable } \\
\text { PLA \& PGA }\end{array}$ & BM-MNCs & Human & 79 \\
\hline
\end{tabular}




\section{Figure 1}

Schematic of the different types of stems that can be used on the biomaterial backbone for cardiovascular Tissue Engineering (TE)

This schema represents the different types of stems that can be used on the biomaterial backbone (depicted as the background characters) for cardiovascular Tissue Engineering (TE). A) Induced pluripotent stem cells (iPSCs) derived from fibroblast. B) Prenatal, Perinatal, and Postnatal Stem cells (PPPSCs) are derived from amniotic fluid, umbilical cord, and chorionic villi. C) Bone Marrow Stem Cells (BMSCs) such endothelial progenitor cells (EPCS) and Mesenchymal stem cells (MSCs) can easily be isolated from the bone marrow. D) Cardiac progenitor cells (CPCs) can be harvested during palliative surgery or endomyocardial biopsy. E) Embryonic stem cells (ESCs) derived from the inner cell mass of the blastocyst

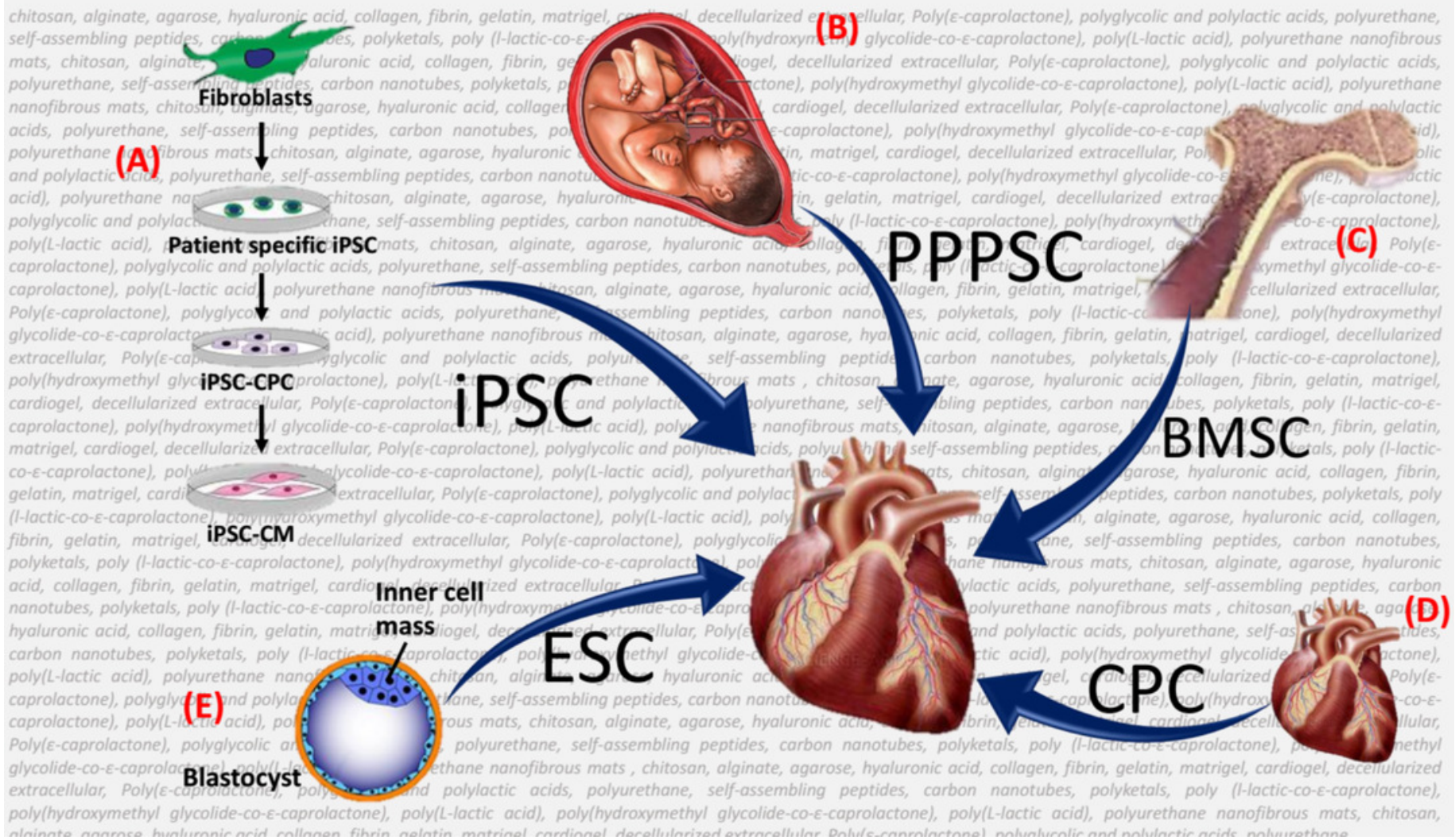




\section{Figure 2}

Promising strategies for CHDs treatment

The schematic diagram represents the potential of Stem Cells (SCs) and Tissue Engineering (TE) for corrective surgical treatment of infants as well as adolescent patients with Congenital Heart Disease (CHD). Various sources for Stem Cells (SCs) are presented here as alternatives to harvesting the appropriate Stem Cells (SCs) which can be used to seed on clinically certified biomaterial scaffolds for reconstructing functional cardiac tissueengineered grafts. These grafts could be implanted via the corrective surgery into the heart of infants and adolescent patients with Congenital Heart Disease (CHD) for definitive correction of cardiac defects. These optimized cardiac-tissue engineered grafts should have the potential to grow in parallel with the child, while are lacking any tumorigenicity, immunogenicity, thrombogenicity, calcification, and other risk factors. 


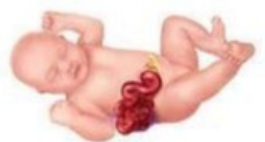

Umbilical cord blood Heart biopsy of newborn

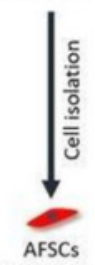

UCB-EPCS

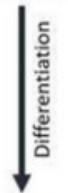

$-$

$\mathrm{CMCS}+\mathrm{ECS}+\mathrm{SMCS}$

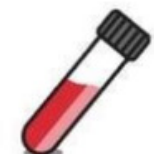

Peripheral blood

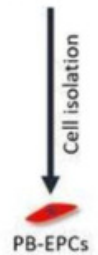

PB-MNCS

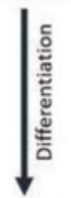

.

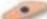

$\mathrm{CMCs}+\mathrm{ECs}+\mathrm{SMCs}$

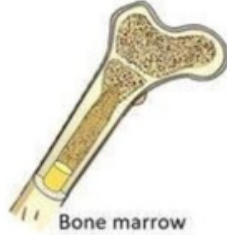

sample

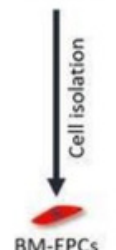

M-MNCs

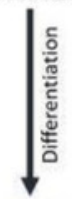

-

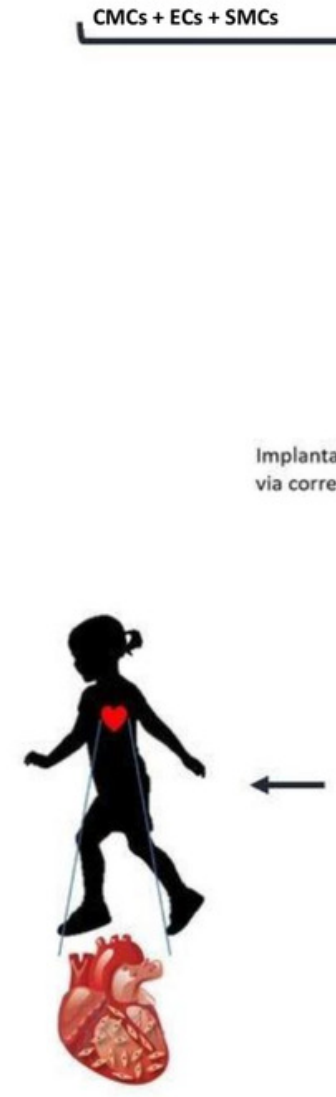

Adaptability of EPGs with growing body \& accepable heart correction

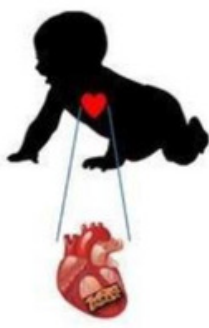

EPGs implantation to Infant $\mathrm{CHD}$ patient

$\mathrm{CMCs}+\mathrm{ECS}+\mathrm{SMCs}$

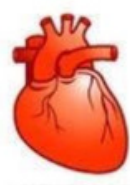

Heart biopsy

sample
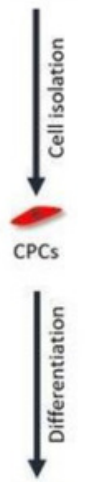

$\rightarrow$

$\mathrm{CMCs}+\mathrm{ECs}+\mathrm{SMC}$

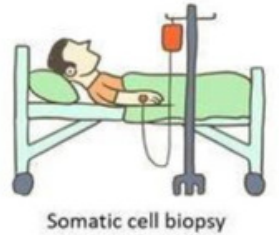

from patient

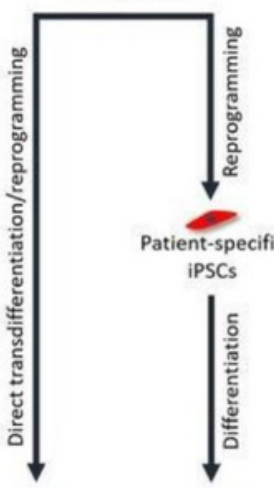

-

$\mathrm{CMCS}+\mathrm{ECS}+\mathrm{SMCS} \quad \mathrm{CMCS}+\mathrm{ECS}+\mathrm{SMCS}$

Engineered

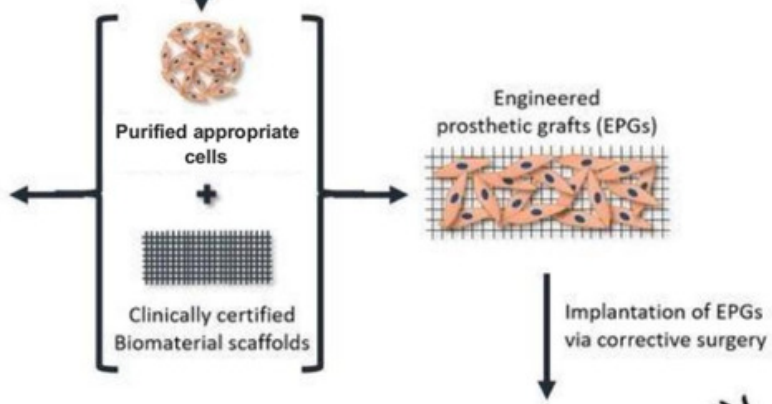

Engineered prosthetic grafts (EPGs)

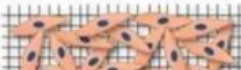

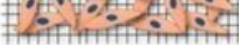
mplantation of EPGs a corrective surgery

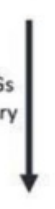

Clinically certified via corrective surgery
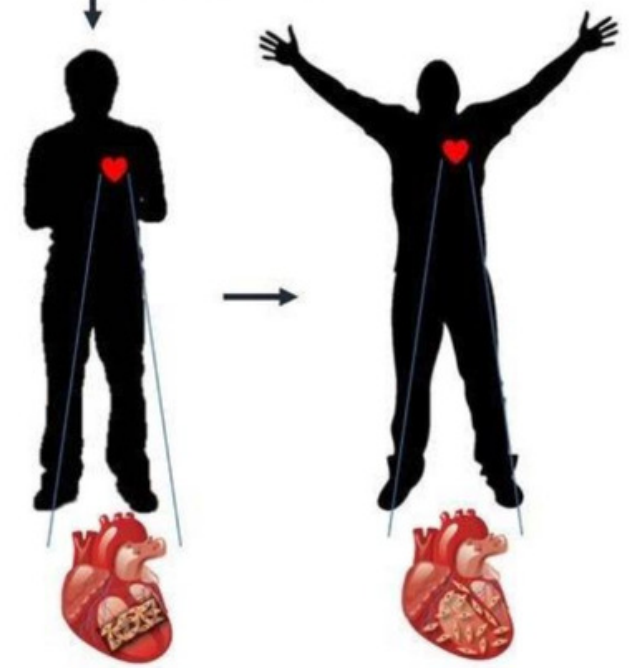

EPGs implantation to adult $\mathrm{CHD}$ patient \& accepable heart correction 